\title{
The Influence of L2 Transfer on L3 English Written Production in a Bilingual German/Italian Population: A Study of Syntactic Errors
}

\author{
Helen Forsyth* \\ Free University of Bozen-Bolzano, Piazza Università 1, Bolzano-Bozen, Italy \\ Email: hforsyth@gmail.com
}

Received 9 June 2014; revised 10 July 2014; accepted 18 July 2014

Copyright (C) 2014 by authors and Scientific Research Publishing Inc.

This work is licensed under the Creative Commons Attribution International License (CC BY). http://creativecommons.org/licenses/by/4.0/

(c) (7) Open Access

\begin{abstract}
This study attempts to examine and identify instances of negative "interlanguage transfer" (Sharwood Smith \& Kellerman, 1986), which is a phenomenon belonging to the broader field of crosslinguistic influence, in written L3 English production in a bilingual Italian/German population. Transfer from learners' L2 has attracted increasing attention over recent years (De Angelis \& Selinker, 2001; Jessner, 2006) and research has suggested various potential triggers for facilitative and negative $\mathrm{L} 2$ transfer, as well as producing mixed results regarding the individual aspects of language that may be susceptible to transfer from a learner's L2. Quantitative data were collected from 46 subjects in the form of questionnaires enquiring about language backgrounds and attitudes, and written summaries. The Statistical Package for Social Science was used to analyse specific instances of written syntactic errors resulting from both L1 and L2 transfer and these were then examined in the light of the questionnaire responses in order to identify possible determining factors behind any $L 2$ transfer for both linguistic groups. Results provided evidence of negative syntactic L2 transfer from German and Italian in English L3, yet the possible determining factors were sometimes unexpected and not necessarily identical for both groups. This study suggests that L2 transfer in multilingual settings is a very real possibility which may be of future interest in terms of multilingual language processing and have consequences for the L3 classroom.
\end{abstract}

\section{Keywords}

Cross-Linguistic Influence, L3 Classroom, Syntactic Errors

${ }^{*}$ The author was studying at the Faculty of Education and Society, University of Sunderland, Edinburgh Building, City Campus, UK, at the time of writing the paper.

How to cite this paper: Forsyth, H. (2014). The Influence of L2 Transfer on L3 English Written Production in a Bilingual German/Italian Population: A Study of Syntactic Errors. Open Journal of Modern Linguistics, 4, 429-456. 


\section{Introduction}

Bilingualism is at least as frequent in the world as pure monolingualism (Hammarberg, 2001; Jessner, 2006), yet the predominant approaches to English language teaching have been influenced to a disproportionate degree by cultures which fail to represent or understand the bi- or monolingual global norm. As a result English language teaching fails to adequately recognize that members of bilingual communities find themselves with more than one linguistic system available to draw on when it comes to both production and reception in a third subsequently acquired language. This may result in greater cross-linguistic awareness in L3 learners (Jessner, 2006) and constitute an advantage in terms of metalinguistic awareness when compared with monolinguals. Failure to take advantage of these paedagogic opportunities is to the detriment of learners and may result in demotivation and a mismatch between instructional methods and learners-a situation which could result in frustration and decreased motivation. If the influence of multiple language systems evident in bilingual learners can be demonstrated, then the suitability of monolingual language teaching approaches can reasonably be called into question. Accordingly, this study examines and identifies instances of negative "interlanguage transfer" (Sharwood Smith \& Kellerman, 1986) or "non-native language transfer" (ibid.) in written L3 English using a data sample from 46 members of a bilingual Italian/German population. The study seeks to provide significant evidence as to whether bilingualism has the potential to interfere with productive and receptive skills by influencing errors occurring as a result of negative transfer from the L2 in addition to L1. The value of these data would be to substantiate the argument that "acquired language systems do not exist side by side in 'mutual harmony' but start to interfere with each other” (Herdina \& Jessner, 2000: 90), thus paving the way for English language teachers and researchers to develop case-specific local language-learning programmes which more intelligently consider learners' linguistic resources.

\section{Definition of Terms}

Transfer from a learner's L1 or mother tongue to their L2 has long been a field of research (Corder, 1967; Weinreich, 1953). Weinreich used the term "interference" to describe "instances of language deviation from the norms of either language which occur in the speech of bilinguals as a result of their familiarity with more than one language", denoting a negative influence which impedes or "interferes" with correct L2 production. Once this L1 influence was seen to also have a facilitative effect, the term "transfer" was adopted, which may be either positive or negative. Odlin provides a general definition of transfer that may take into account its various aspects:

"(transfer is)...the influence resulting from similarities and differences between the target language and any other language that has been previously (and perhaps imperfectly) acquired" (Odlin, 1989: 27).

While Ellis states quite simply that, "(transfer is) influence that the learner’s L1 exerts on the acquisition of an L2” (Ellis, 1997: 51).

Various subsequent Second Language Acquisition (SLA) theories and models took transfer into account, including Krashen's Monitor Model Hypotheses (1982), which recognize the potential for negative transfer from a learner's L1, and Eckman's Markedness Differential Hypothesis (1977). Pienemann's original Processability Theory $(1984 ;$ 1998), however, does not allow for transfer in a learner's developing grammar (Bardel \& Falk, 2007). Interestingly, on the subject of research on positive versus negative transfer, Ringbom has remarked that "The concept of similarity in SLA research has been far less interesting to linguists than the concept of difference” (2005: 78). This may be due to the comparative ease of identifying negative transfer when compared with positive transfer. He stated back in 1986 that:

"It is difficult to determine exactly the extent of positive influence, compared with negative influence, since the only tangible signs of cross-linguistic influence are negative ones" (1986: 160).

Behaviourist views of transfer refer to "the influence of already established linguistic habits on the learning of new habits” (Faerch \& Kaspar, 1986: 49 cited in Kellerman, 1983), which is seen as automatic and involuntary. Within a cognitivist paradigm, however, "transfer has been characterized as a problem-solving procedure, or 'strategy', utilizing L1 knowledge in order to solve a learning or communication problem in L2" (ibid.), and conscious decisions are made during the process.

Transfer is to be understood as distinct from "code switching" or "lexical borrowing", which occur when two language communities are in contact. The first term involves the intentional juxtaposition of L1 and L2 elements where this "does not violate a syntactic rule of either language" (Poplack, 1980: 586) and may in some cases be 
mistaken for negative syntactic/morphological transfer. Lexical borrowing, on the other hand, implies the intentional incorporation of whole words from the learner's L1 into the L2, often due to a "lack of vocabulary in a language” (Holmes, 2008: 43). Cenoz differentiates between “interactional strategies”, which are intentional switches into languages other than the target language, similar to code switching, and "transfer lapses", which are non-intentional switches “when another language has been erroneously accessed” (Cenoz, 2003: 107), relating to the type of transfer which is the subject of this study.

Sharwood Smith and Kellerman's (1986) broad definition of cross-linguistic influence as "the interplay between earlier and later acquired languages” (ibid., 1986: 1) has come to account for a variety of different scenarios, including avoidance, borrowing, L2-related aspects of language loss and transfer from L2 to L3. The more recent field of L2 transfer follows on from studies on multilingualism and the need to explain phenomena relating to multilingual competence. Jessner states that:

"Experienced learners express their cross-linguistic awareness by making use of two supporter languages during the production of the third (typologically related) language” (2006: 114).

Bouvy describes L1 transfer as having cognitive aspects, yet L2 transfer as depending on context and situation, being "simply a performance-induced phenomenon, brought about by virtue of learners" use of the semantic-syntactic access file to the "mental lexicon' in the production task” (2000: 144). De Angelis and Selinker indicate that research into L2 transfer instead of L1 transfer is, in fact, still in its infancy and regret that "current language transfer theories are highly restricted, being primarily based on the interaction between two systems" (2001: 44).

Central to De Angelis and Selinker's 2001 study is the concept of interlanguage, a term coined by Selinker (1972) in his Interlanguage Hypothesis. Selinker interprets interlanguage as:

"the linguistic system based on observerable output which results from a learner's attempted production of a TL (=target language) norm” (Selinker, 1972: 214).

In Crystal's Dictionary of Linguistics and Phonetics, interlanguage is defined as:

“[Interlanguage] reflects the learner's evolving system of rules, and results from a variety of processes, including the influence of the first language ('transfer'), contrastive interference from the target language, and the overgeneralization of newly encountered rules.” (Crystal, 1997).

Since 1972 interlanguage has been used as a term to describe the stage learners' L2 is at, rather than comparing L2 competence with native-speaker competence, which condemns learners to a state of perpetual imperfection (Cook, 2005). This concept has been extended to L3 learning, and, in fact, De Angelis and Selinker state that transfer of interlanguage cannot take place involving just 2 linguistic systems: "Technically, interlanguage transfer cannot occur without a minimum of three linguistic systems” (2001: 44), due to the fact that it must involve "the influence of a non-native language on another non-native language" (ibid.: 43).

They go on to emphasize the fact that the L1 may play a less important role than is sometimes assumed:

"We do not have the evidence to claim that native language transfer is always dominant in interlanguage production” (ibid.: 44).

Hammarberg suggests that research has "restricted the scope of investigation to considering just one L2" (2001: 21) and additionally expresses the need to draw a distinction between L2 and L3 acquisition. He claims that:

"The notion of second language acquisition is usually understood in a wide sense where 'second' may refer to any language that the learner had added after infancy" (ibid.).

He calls for an adequate definition of the modern polyglot or multilingual, stating that "bilingualism is usually taken to cover bi- or multilingualism in principle” (ibid.), echoing Haugen’s 1956 reference to multilingualism as a kind of multiple bilingualism, and that the term bilingualism should be adapted to include additional languages acquired after the L2.

These inconsistencies surrounding the distinction between bilingualism and multilingualism and its terminology are outlined by De Angelis (2007), who speaks of a "bilingual bias” in multilingualism research, where multilinguals are viewed as bilinguals with additional languages (2007: 15). Jessner also points out that previously used terms in SLA such as L1 and L2 may become problematic when applied to multilingual competence (2006: 117).

Research on multilingualism as distinct from bilingualism over the years ranges from Vildomec (1963) to Aronin and Hufeisen (2009). Central to this particular study is the assumption that:

“Technically, a speaker of three languages (one native and two non-native languages) may potentially mix the 
components of all his/her language systems, and is faced with the task of keeping his/her languages apart in production” (De Angelis \& Selinker, 2001: 45).

\section{Literature Review}

\subsection{Bilingualism and Multilingualism}

As Cenoz states, transfer to a learner's L2 from a learner's L1 is well documented and enjoys a long tradition (Cenoz, 2001: 1). However, L2 to L3 transfer is a more recent field and marks a shift away from the idea that bilinguals may be viewed as two monolinguals in one on a cognitive level (Grosjean, 1989; Cook, 2005). The examination of to what extent learners of an L2 depend on their native language and compare it with their L2 to aid them in their L2 acquisition has its roots in Fries' 1945 work relating to coursebook design. Lado's “Theories of Contrastive Analysis" (1957) were developed later, which further stressed learners' reliance on their L1 syntax in target language acquisition. Schachter's 1974 study "An error in error analysis” found evidence from Asian learners of English indicating that:

"The learner apparently constructs hypotheses about the target language based on knowledge he already has about his own language" (1974: 212).

These and similar studies led to attention to the phenomenon of negative transfer. Cummins' 1991 "Interdependence Hypothesis" identified cognitive effects of transfer and emphasized that certain first language knowledge can be transferred to the second language with beneficial results.

The first authoritative works on bilingualism include Weinreich's 1953 “Languages in Contact” and Haugen's 1956 "Bilingualism in the Americas". Studies in bilingualism, however, were kept apart from SLA research, as they were considered to stem from the differing backgrounds of sociolinguistics and pedagogical research respectively (Jessner, 2008; Clyne, 1997).

Many definitions have been proposed to describe and categorise types of bilingual competence. Early on, Bloomfield described a bilingual as having "native-like control of two or more languages" (Bloomfield, 1933). Weinreich contrasted between "compound" and "co-ordinate" bilinguals. Compound bilinguals are said to acquire both languages at the same time or in the same context, as in during childhood, and therefore have an identical mental representation, yet two verbal representations, for a single concept. On the other hand, co-ordinate bilinguals learn two languages in two distinctly separate environments, meaning that words for a single concept take on differing meanings (Romaine, 1995). Rosenberg's (1996) work involving bilingual children uses the terms "balanced bilingualism" to describe individuals who possess about the same fluency in two languages, and "semilingualism" for those individuals who have deficiencies in both languages compared with monolinguals. Safont Jordà has gone as far as providing a detailed breakdown of all possible types of bilinguals (1995: 26-27). Cook, on the other hand, warns against the use of the term "bilingual" and prefers the term "second language users" to describe those engaged in real-life use of the L2 as opposed to "L2 learners" (Cook, 1992, 1994, 2005 cited in Jessner, 2006: 10). Grosjean's research on bilingualism outlines a bilingual continuum, ranging from the monolingual to the bilingual end, down which bilinguals travel (Grosjean, 1989: 8-9).

Defining multilingualism as distinct from bilingualism is not an easy task. Jessner states:

"Finding a definition of multilingualism can be described as one fo the most daunting research questions of current linguistics.” (2008: 20).

Multilingualism encompasses bilingualism, yet research into multilingualism is more complex, as:

"It has to take into account the implications that the knowledge of more than the first language has on the acquisition of an additional language or the multiple relationships between the different linguistic systems in language comprehension and production" (Cenoz et al., 2003: 2).

Despite early suggestions (1960s) that bi- or multilingualism had a detrimental effect on children's development, as documented by Grosjean (1989), subsequent research has suggested that multilinguals have a cognitive advantage over monolinguals (Bialystok, 2004; Ringbom, 1987). Cummins' 1976 Threshold Hypothesis aimed to explain some of the phenomena associated with bi- and multilingual development and at which levels of competence bilingual/multilingual learners may benefit from the cognitive and academic advantages their linguistic diversity brings. Ò. Laoire and Aronin (2004) distinguish between the notions of "multilingualism" and "multilinguality", suggesting that multilinguality involves additional sociolinguistic aspects such as social ties and influences, anxiety and reference group (cited in Jessner, 2006: 11). Interestingly, the field of multilingualism appears to be mainly investigated by non-native speakers of English. Hufeisen and Fouser mention that 
there are few native English speakers researching multilingualism, especially in North America, where "multilingualism is viewed as too rare and too case-specific to waste valuable research resources on” (2005: 34). A clear distinction now exists between SLA and Third Language Acquistion (TLA), rather than L3 acquisition being viewed as another case of L2 acquisition. Rothman and Cabrelli state that:

"Over the last decade or so, it has been acknowledged that the existence of two already-acquired language systems at the onset of L3 acquisition makes this process unique and worthy of study in its own right” (2009: 2).

\subsection{Bi- Or Multilingualism and Monolingualism}

Research suggests that bi- or multilinguals are “different” from monolinguals, not just on a sociolinguistic level due to their close contact with two language communities, but on a cognitive plane. Grosjean portrays the bilingual as "a competent but specific speaker-hearer" (1989: 6) with a "unique and specific linguistic configuration" (ibid.: 3) who activates "language modes" (2001: 2) depending on the situation. A "language mode” describes "the state of activation of the bilingual's language processing mechanism at a certain point in time" (ibid.). Connected with Grosjean's idea that bi- and multilinguals are not just two or more monolinguals rolled into one, Cook proposes the idea of “(w)holistic multicompetence”, reflecting a distinct state of mind (1992: 558). This multicompetence, involving familiarity with more than two languages, is contrasted with monolingual competence in a number of studies (Cenoz and Genesee, 1998; Cook, 1992; Grosjean, 1992; Herdina \& Jessner, 2000).

Levelt (1989) proposed a speech processing model to explain monolingual processing, which other researchers have taken as the basis for their accounts of multilingual processing (Bialystok, 1993; Clyne, 2003; De Bot, 1992). Clyne states that, although L3 learners used processes that are similar to those of L2 acquisition, "the additional language complicates the operations of the processes” (1997: 113). These multilingual models, along with Hufeisen's Factor Model (1998), have attributed to bi- and multilinguals a heightened level of metalinguistic awareness when learning an L3. Jessner claims that:

"The L3 learner already knows about the foreign language learning process and has (consciously or unconsciously) gathered individual techniques and strategies to deal with such a situation with differing degrees of success” (2008: 23).

She adds "It should be pointed out that at this stage the L2 will probably take over the role of a bridge or supporting language in TLA development” (ibid.). The possibility of L2 transfer, both facilitating and impeding, becomes a very real possibility at this point, despite, or possibly also because of, L3 learners' increased metalinguistic awareness.

Specifically related to German/Italian bilinguals, and therefore particularly relevant to this study, are Bassetti's 2007 study on bilingual children and Jessner's 2006 Tyrol study involving bilingual students at Innsbruck University. These demonstrate the altered cognitive processes of German/Italian bilinguals compared to monolinguals and demonstrate frequent lexical transfer from learners' L2 in L3 English production respectively.

\subsection{Learner and Language-Based Variables Influencing L2 Transfer}

For the purposes of this study, the concepts of learning and acquisition are used interchangeably and not in accordance with Krashen's 1992 definitions.

Various studies have put forward possible factors conditioning L2 transfer:

1) Typological similarity or language distance: Kellerman introduced the concept of typological proximity, or “psychotypology”, between languages in his 1983 study. According to this, influence from a learner's L2 is favoured if they consider their L2 to be typologically close to their L3, especially if their L1 is more distant. This occurs more often when learners have non-European languages as their L1, as Ringbom claims to be the case with Asian learners of English and French (Ringbom, 2001) particularly regarding lexis, and as Vogel demonstrated in his study with Chinese learners of German and English (Vogel, 1992). More recently, Rothman detected L2 syntactic transfer due to typological similarity between European languages (Rothman, 2010). Schmid (1996) introduces terms such as congruence, or "identification of interlingual correspondence”, correspondence, or "the development of processes to relate similar forms in the related L2 and L3", and difference, or "the identification of contrasts between the languages" (Clyne, 1997: 102) that "are all employed as learning strategies to facilitate extension of competence from a Stützsprache (supporting language) to Zielsprachen (target languages)” (ibid.). Paradis (1987), in a study on aphasia in bilinguals, similarly relates joint or separate storage of language to language distance. 
Although learners’ perceptions of language distance (Kellerman, 1983; Ridley \& Singleton, 1995) may trigger or constrain language transfer, these perceptions may not correspond to the actual, legitimate distance between languages (De Angelis 2001: 55), which is based on genetic factors and typological classification (Croft, 2003). To investigate syntactic transfer it is necessary to examine some concepts in the field of language typology and distinguish between actual typological and perceived distance between languages. According to Greenberg (1974), the word "typology" only gained wide currency in linguistics after circa 1928 and is the field of study that sets out to describe the differences between languages (1974: 13). The study of language "universals", on the other hand, tends to focus on what languages have in common and attempts to make generalizations about languages (ibid.; Croft, 2003). The study of individual and specific aspects of typology such as certain grammatical structures is referred to as "partial typology" (Shibatani \& Bynon, 1995: 9). This is contrasted with the $19^{\text {th }}$ century idea of "holistic typology", which focuses on the study of a small area of language in order to gain insight into the entire language and involves all levels of linguistic structure (phonology, morphology and syntax) (ibid.) Cenoz states that:

"Language typology has a historical origin and cannot be studied without considering the history of the language and the language contact situations" (2003: 105).

This notion of typology, also known as "prototypology", may be different to "psychotypology", or "the individual's perception of language distance” (ibid.). Learners' beliefs about language distance may therefore be considered a subjective factor which is not necessarily governed by the properties of the languages involved, but by how they experience them in relation to each other.

In terms of actual, legitimate prototypology, although the languages in this study (German, Italian, English) are Indo-European languages and therefore share universals such as being mostly right-branching rather than left branching, synthetic rather than analytic (Croft, 2003: 46) and tend to be SVO languages in their main clause structure with the subject always preceding the object (Greenberg, 1974), variation in numerous structural features may nevertheless be found.

2) Affective and cognitive factors: Singh and Carroll (1979) suggest that learners' identifying more strongly with an L2 than an L1 may influence their L3 learning in the form of transfer. Hammarberg similarly speaks of a degree of "cultural identification" involved in learners' choice of what he calls "external instrumental language" in a polyglot speech situation (2001: 36). Spoken production appears to be more affected by this than written production, confirming De Bot's 1992 findings on affective factors. Hammarberg states: "De Bot assumes that the bilingual speaker's languages may be activated to varying degrees in a speech situation” (2001: 24). Kellerman (1995) detects differences between formal and informal settings, in that learners tend to experiment more with language when they are outside the classroom. De Angelis (2007) suggests that increased formality of context, along with the fear of failure and peer pressure, involves a certain degree of stress, and that this may lead to reduced L2 transfer. Dewaele (2001), too, found that Dutch L1 and English L2 or L3 learners produced fewer mixed utterances when speaking French in a formal situation compared with during an informal interview.

With Dutch L1 learners of English L2, Kellerman (1995) found that formal settings may lead to a certain type of cross-linguistic influence known as "avoidance", whereby learners underproduce certain target language forms due to a lack of trust in corresponding structures between languages (Schachter, 1974):

"The perception of radical differences in form between functionally equivalent L1 and L2 structures may cause learners to underproduce these L2 structures" (Schachter, 1974 cited in Kellerman, 1995: 131).

This may be explained as a faulty self-assessment of their "ignorance" (Jessner, 2003: 53).

Odlin's definition of avoidance, on the other hand, relates to learners' perceptions of languages being distant:

"If learners sense that particular structures in the target language are very different from counterparts in the native language, they may try to avoid using those structures" (Odlin, cited in Jessner, 2003: 54).

In 1983 Meisel introduced the notion of "foreign language effect" to describe the impact of an L2 on L3 phonological performance. Selinker and Baumgartner Cohen (1995) similarly identify a "foreign language mode" or "talk foreign" in spoken language, which they suggest may facilitate the path of interlanguage transfer in that speakers do not want to "sound" as if they are speaking their native language. De Angelis and Selinker claim that "the use of an interlanguage, perceived by the speaker as "foreign", may well be preferred over the use of the native language, particularly in spontaneous oral L3 production, because it "sounds" more foreign than the native language does” (2001: 56). De Angelis and Selinker go on to state that learners' own perceptions of their interlanguage competence may affect choice of transfer (ibid.), which has also been suggested by Dewaele (2001). Even memories of speaking a non-native language in a particular environment may activate an L2 in L3 
production. Cohen describes an English L1 trilingual who states: “sometimes when something triggers a memory of being abroad where I spoke an L2...I think in the language I used at the time” (Cohen, 1995: 102). This may also be related to the L2 exposure factor.

3) L2 proficiency and exposure: Hammarberg states that high levels of competence in a learner's L2, along with its having "been acquired and used in natural situations”, may favour L2 transfer (Hammarberg, 2001: 23). Ringbom also proposes that the extent of L2 transfer depends on the extent of exposure to the L2, along with L2 proficiency, particularly when it comes to grammar (Ringbom, 2001). Learners' belief in their interlanguage competence may play a role:

"At the initial stages of third or additional language acquisition, a learner may perceive his/her own competence to be too low to be willing to risk incorporating previous linguistic knowledge in the target language” (De Angelis and Selinker, 2001: 56).

Similarly, Grosjean has noted that bilinguals often criticize their own language competence (Grosjean, 1989), which in some cases could lead to L2 proficiency being quite a subjective factor.

4) Recency and order of acquisition: Hammarberg reports a pronounced tendency to activate an L2 that has been used recently and to activate an earlier secondary language in L3 performance rather than the L1 (Hammarberg, 2001). As far back as 1963, Vildomec likewise suggested that non-native transfer was more likely to occur if this language was fresh in the user's mind. Concerning order of acquisition, Dewaele (1998) found that the frequency of lexical inventions in the French oral production of Dutch L1 learners with English as an L2 or L3 was largely dependent on the order in which they had acquired their L2 and L3. The prior acquisition of an L2 influences language processing in multilinguals due to that fact that:

"Multilinguals could use different processing and acquisition mechanisms for second languages as compared to first languages” (Cenoz, 2003: 106).

5) Age: Selinker and Lakshmanan found that L2 acquisition is governed by Chomsky's concept of Universal Grammar (1957) in young children and target language input rather than any recourse to their L1, thus excluding the likelihood of transfer (Selinker \& Lakshmanan, 1993). Extended to L3 learning, Cenoz found that older learners use more cross-linguistic influence than younger ones in a study of Basque and/or Spanish-speaking students aged 7 - 15. This may be linked to increased metalinguistic knowledge and awareness of language distance of older learners rather than any cognitive factor (Cenoz, 2001: 16).

An attempt to ascertain which, if any, of these language- and learner-based variables may be involved in German/Italian L2 negative transfer in English L3 is the focus of the items in the preliminary questionnaire.

\subsection{Models Explaining L2 Transfer}

Research into the potential influence of their L2 on multilingual speakers' L3 rapidly followed after the coining of the term “cross-linguistic influence” by Kellerman and Sharwood Smith (1986). During the 1990s various models were developed in an attempt to explain the phenomenon (Hufeisen, 1993; Shanon, 1991; Sikogukira, 1993; Williams \& Hammarberg, 1998).

According to Schwartz and Sprouse (1996), the L1 fully determines the acquisition of any non-native language. Previously, Magiste (1984) had investigated Swedish bilinguals and monolinguals learning English and, after finding no differences between the two groups' English comprehension and grammar performance, concluded that "the potential for (L1) interference increases with the number of languages a student knows" (cited in Klein 1995: 427). This concept is known as the Full Access/L1 Transfer Hypothesis (Schwartz \& Sprouse, 1996), which holds that there is an L1 effect for all adult acquisition.

Shanon (1991) proposes the "last learned language effect" to account for reduced L1 influence in L3 errors, while Williams and Hammarberg (1998), Bardel and Falk (2007) and Rothman and Cabrelli (2009) suggest that a learner’s L2 blocks L1 transfer and complicates access to the L1 (the L2 Status Factor), being more recently and formally acquired than the L1. In their recent 2011 study, Bardel and Falk stress:

“...the importance of the L2 status factor, i.e. we assume that secondary languages differ cognitively from first languages and will therefore be preferred as transfer source in case of L3 acquisition.” (2011: 61).

They apply this primarily to the initial state of L3 acquisition and particularly to morphosyntactic transfer.

The Cumulative Enhancement Model (CEM) (Flynn et al., 2004), on the other hand, suggests that selective positive transfer takes place from all previous linguistic knowledge and that prior language acquisition has a scaffolding effect (Rothman, 2011: 110). Flynn et al. ask: 
"Specifically, does the L1 maintain a privileged role in all subsequent language acquisition or is it possible that all languages known can play a role in subsequent language acquisition?” (2004: 3).

The type of transfer taking place according to this model is either neutral or facilitative.

Missler (1999) similarly claims that the more foreign languages learners know, the more they can make use of their knowledge in learning additional languages (cited in Hufeisen et al., 2005: 40). However, Rothman and Cabrelli question the "tenability of certain aspects of CEM" in their 2009 study, preferring their Typological Primacy Model (see below).

Hall and Ecke (2003) developed the Parasitic Model to explain exclusively lexical transfer. This shares similarities with the CEM in that:

"According to the Parasitic Model, new lexical representations will be integrated, where possible, into the rest of the network via connections with pre-existing representations ('hosts') at points of similarity or overlap between them" (2003: 72).

This may also apply to L3 learning, as they state that empirical studies have shown "the frequent involvement of similar L1, L2 or L3 structures in the construction and use of the L3 lexicon" (ibid.).

Their concept of "total parasitism" in the trilingual lexicon implies that all three languages "serve as sources of lexical influence on each other and on themselves" (ibid.: 79), sometimes leading to "the interlanguage phenomena known as errors" (ibid.).

Hakansson et al.'s Developmentally Moderated Transfer Hypothesis (2002) accounts for transfer within Pienemann's (1998) Processability Theory, yet argues against the existence of syntactic transfer from the L2.

Building on Kellerman's concept of psychotypology, the Typological Primacy Model (TPM) was developed by Rothman and Cabrelli in 2007 to explain morphosyntactical transfer to the L3 due to an L2's perceived similarity to the L3. Rothman claims that:

"Initial State transfer for multilingualism occurs selectively, depending on the comparative perceived typology of the language pairings involved, or psycho-typological proximity. Syntactic properties of the closest (psycho)-typological language, either the L1 or L2, constitute the initial state hypotheses in multilingualism, whether or not such transfer constitutes the most economical option.” (2011: 7).

Consequently, this "comparative perceived typology of the language pairings involved" may be highly subjective. Rothman further extends this model to later developmental stages of L3 learning and claims that it holds true for any level of L3 proficiency, providing that successful L2 and L3 acquisition of the properties under investigation has taken place (2011: 7).

Selinker and Lakshmanan (1993) developed the Multiple Effects Principle, which holds that "language transfer tends to be the axis of multiple factors" in second language learning (ZhaoHong, 2004: 118). This was found by Murphy (2003) to apply to L3 learning, and that a number of the variables listed in Section 3.3 may be involved, particularly regarding speech production.

All of these models provide food for thought regarding the reasons behind L2 transfer in L3 production and deserve some examination for their relevance to this particular study.

\subsection{Areas Where L2 Transfer Is Possible}

It appears that previous research in L2 transfer has primarily addressed spoken rather than written production (Dewaele, 1998; De Angelis, 2007; Hammarberg, 2001; Ringbom, 2001). Those studies focusing on written production and consequently relevant to this study include Rothman and Cabrelli's 2009 study on grammaticality judgement and a study by Sikogukira (1993) involving written production in the form of sentence completion tasks. Additionally, Sagasta Errasti (2003) recruited samples of written tasks to evaluate Basque/Spanishspeaking learners of English L3.

De Angelis (2007) has identified the following areas where both positive and negative L2 transfer may be possible:

- Lexis

- Phonetics and phonology

- Morphology

- Syntax

Lexis: In 2001 Grosjean proposed the BIMOLA bilingual model of lexical access (Grosjean, 2001), and, to date, lexical L2 transfer appears to be the area that has attracted the most attention in L2 transfer research. Hall 
and Ecke's Parasitic Model focuses on L3 vocabulary acquisition (2003) and Ecke's 2001 study divides L3 cross-lexical errors up into four categories: meaning, syntactic, form, form/meaning (Ecke 2001: 93). Along with morphological transfer, De Angelis and Selinker identify lexical interlanguage transfer as one of the subtypes of transfer (2001: 43). Their study sets out to show that:

"both lexical and morphological transfer must be handled in any general theory of cross-linguistic influence in terms of some cognitive constraints on interlanguage production" (ibid).

Regarding negative lexical transfer, Ellis (1994) has claimed that semantic aspects of language are more difficult to grasp than aspects of form as learners progress in any foreign language, and Green (1986) mentions L3 errors in vocabulary acquisition resulting from a lack of resources. Regarding positive lexical transfer, Jessner's Tyrol study found that L1 German "students made use of Italian cognates as a back-up for their lexical decisions in English" (2006: 114) and she frequently noted such L2 compensatory strategies being used to overcome lexical problems (2006: 90). For semantic transfer to a learner's L3 to occur in the first place Ringbom claims that learners' proficiency in their L2 has to be high (cited in De Angelis 2007: 34). Conversely, De Angelis found that transfer regarding rate of subject insertion and omission from a little-known language (French) may also occur (2007: 35).

Phonetics and phonology: Williams and Hammarberg claim that "Compared with the extent of L1-transfer, L2-transfer seems to be of relatively slight importance in phonology" (2005: 78). However, De Angelis demonstrates an English L1 speaker and beginner in Swedish consciously using the phonetic settings of German when speaking Swedish, thus avoiding unwanted L1 phonetic features such as dipthongal vowel qualities (2007: 52). Hammarberg and Hammarberg (1993) suggest that this is a type of:

"coping strategy which the learner resorts to at an initial stage when the phonetic form of L3 is too unfamiliar to master, and abandons when proficiency increases" (De Angelis, 2007: 52).

Other studies observing this phenomenon are Chamot (1973), involving a French/Spanish bilingual learner of L3 English, and Singh and Carroll (1979), involving Turkish native speakers learners of L3 English with French L2. Meisel's “foreign language effect” (1983) may also be strong in phonological performance.

Morphology: There is some scepticism surrounding the transfer of bound morphemes and inflectional morphology from both L1 and L2 (De Angelis, 2007: 54), and Odlin (1989) claims that bound morphemes are generally less susceptible to transfer than other features. However, as far back as 1953, regarding bilingualism, Weinreich claimed that "transfer of morphemes is facilitated between highly congruent structures" (1953: 33), and Hammarberg (2001) offers some examples of transfer of inflectional morphemes from a non-native language. Rothman and Cabrelli claim that, in contrast with studies on lexis, "the few existing formal linguistic studies at the morphosyntactical level offer contrary conclusions” (2009: 2).

Syntax: Dewaele states that "crosslinguistic transfer is easier to determine at the lexical than at the syntactic level” (1998: 488). Hakansson et al.’s 2002 Developmentally Moderated Transfer Hypothesis argues against syntactic transfer from L2 to L3 altogether, although Bardel \& Falk’s 2007 study presents counter-evidence to this and claims that syntactic structures are more easily transferred from L2 than from L1, although only at the initial state of L3 acquisition. Vogel's 2005 study with a Chinese learner of L2 English/L3 German suggests that L2 influence on a syntactic level does not take place, but "is confined to the lexicon” (2005: 115). Ringbom also claims that L2 transfer is clear in lexis, but less so in grammar, which is "nearly always L1-based, or at least presupposes L2-input or L2 proficiency closely approaching that of the L1” (2001: 67). This is, again, contrary to Bardel and Falk's findings regarding proficiency (2007). Morphosyntactical transfer, or transfer of form, was found by De Angelis and Selinker (2001) to be more evident than transfer of meaning, or semantics, in languages that are typologically related. Language typology may also play a role, and Williams and Hammarberg argue that a variety of elements may be involved:

"the extent of grammatical L2-influence seems to very greatly depend not only on language typology but also on the learner's L2-proficiency, the recency effect and the amount of L2-input" (2005: 78).

Flynn et al. (2004) have detected grammatical transfer from both L1 and L2 and developed the CEM to describe the positive or neutral effects of syntax transfer. Their study demonstrates that learners may draw on their prior knowledge of relative clauses when producing English as an L3. From a generative perspective, Zobl (1992) suggests that multilinguals seem to create less conservative, hence more powerful, grammars than monolinguals do. Klein (1995) also found that multilinguals display an advantage over monolinguals in the acquisition of preposition stranding and Thomas argues that multilinguals possess better metalinguistic skills (1988). 
Both of these factors "contribute to triggering the settings of Universal Grammar parameters in multilingual speakers” (De Angelis, 2007: 59).

Research surrounding L2 transfer in L3 production has produced mixed results regarding the possibility of syntactic transfer and extends from transfer of the facilitative to the negative kind. This study follows on from the relatively few studies on negative L2 syntactic transfer to date, and aims to contribute towards research on cross-linguistic influence and be of relevance for multilingual communities elsewhere.

\section{Methods}

\subsection{Contextual Background to the Study}

Data was collected from students following obligatory instruction in English at a tertiary level education college for healthcare professions in Bolzano/Bozen, the provincial capital of the multilingual region of Alto Adige/Südtirol in Northern Italy (see Figure 1). South Tyrol is a border region, not only in the sense that that it is adjacent to Austria in the north and Switzerland in the west, but in the sense that the region is "an area or space, where different cultures-represented by different languages-meet, mingle or (have to) co-exist." (Vogel et al., 2007: 210).

The ethnically German-speaking region, which lies at the geographical and historical crossroads between German-speaking northern Europe and modern Italy to the south, was until 1918 part of the Austro Hungarian empire and before that the County of Tyrol, part of the Holy Roman Empire. In 1919 the region was ceded to the Kingdom of Italy and under Mussolini's fascist government a program of Italianisation was implemented, involving large-scale immigration of workers from other parts of Italy, leading to a dramatic increase in the Italian-speaking population of Bolzano and a handful of other towns. Cultural domination and repression followed, including the banning of the use of German in all official contexts including education and government (Alcock, 1992: 19). The scope of this study does not allow for a detailed account of the path from this "cultural genocide" (ibid.), via the 1946 Paris Peace Agreement (ibid.), to the present levels of autonomous government, fiscal and legislative freedom, and multilingual representation enjoyed by the region today, but the result is that the bilingual status of this region is currently protected, as is freedom of education in the language of choice. Place names must be represented in each language, and bureaucratic communication must be available in each language (Alcock, 2001: 19). Although schools are separated according to language of instruction, students are required to study the language of the other linguistic group from elementary school. As such, a high level of communicative competence in German and Italian is typically very common in all but the most remote mountain communities, and cultural indicators also point to the success of bilingualism in the province. There are four daily newspapers, two Italian and two German, and both languages and the third linguistic group, Ladin speakers, are represented on television and radio. The local university, the Free University of Bolzano/Bozen, requires students to have B2/C1 (in accordance with the Common European Framework of Reference) proficiency in German, Italian and English and courses are taught in all three languages (ibid.: 20). Table 1 shows the percen-

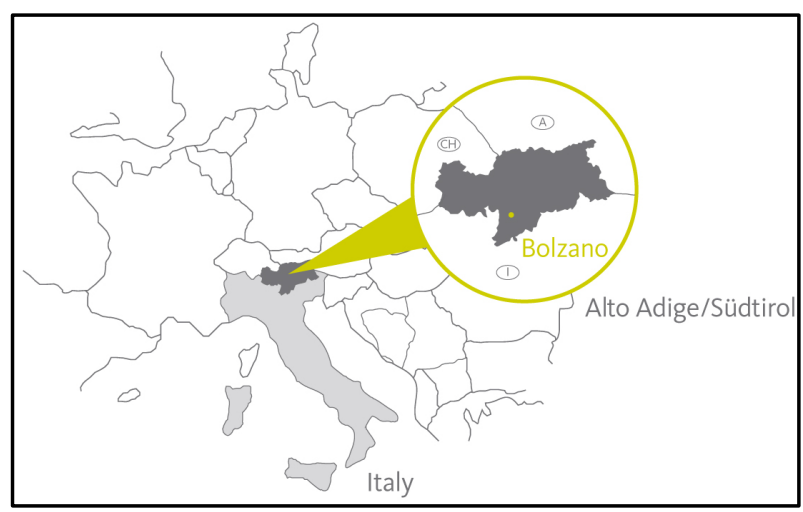

Figure 1. Map showing location of South Tyrol (Alto Adige/ Süd-tirol) with Bolzano/Bozen shown as green dot (http://www.altoadigewinesusa.com/about-alto-adige/). 
Table 1. Percentage distribution of linguistic groups in South Tyrol (Benvenuto, 2010: 15).

\begin{tabular}{ccc}
\hline Language group & In South Tyrol & In Bolzano/Bozen \\
\hline German & 69.38 & 26.29 \\
Italian & 26.30 & 73.0 \\
Ladin & 4.32 & 0.71 \\
\hline
\end{tabular}

tage of speakers who claim to be members of, or be affiliated to, the main languages represented in the province. It should be noted that residents may declare their language affiliation according to the advantages that this may bring them regarding work opportunities in the civil service (including the health service and school system). This is because the proportional system negotiated in the 1972 Package Solution dictates that a certain number of positions are reserved for each of the three language groups (Mikes, 2010: 7).

The data in Table 1 show that the German L1 majority in the whole region is reversed in the regional capital. This indicates the day-to-day functional use of both languages for the inhabitants, as many people may find it necessary to conduct aspects of their lives both inside and outside the urban area. However, although passive exposure to both languages is unavoidable, it must be remembered that if a person is monolingual, or wishes to function in only one language, for whatever reason, it is possible to conduct practically all functions of daily life exclusively using either Italian or German, for example by only patronizing businesses and other situations which use the desired language and avoiding interactions using the other language. This reflects Mansour's concepts of horizontal and vertical bilingualism (Mansour, 1993), where multilingualism is present at a higher level of society, but some individuals may choose not to be bilingual.

It is important not to overgeneralize the situation or participants in terms of bilingual ability. Some areas of South Tyrol are overwhelmingly monolingual in nature for various reasons. These include rural areas which may be geographically, politically and socially closer to Austrian and Germanic culture, or urban neighbourhoods in which society is largely influenced by residents who have moved to Bolzano from monolingual areas of Italy. There is also an increasing number of migrants from other linguistic communities who tend to learn Italian before German, as it is the comparatively easier language and also the language of state bureaucracy. Therefore many individuals may be monolingual, while some members of communities in Ladin-speaking areas can be observed to use three languages in daily life. However, the varying linguistic proportions, from a German L1 majority outside Bolzano, to an Italian L1 majority within the provincial capital, indicate that the majority of the population may be considered to be bilingual on an individual level. Furthermore, there is ample evidence to suggest that the province is bilingual at a community level, thus covering both sociolinguistic and psycholinguistic levels suggested by Baker (2001: 2). Therefore it is valid to view this research context as that of third language acquisition, in that it gathers data from individuals, the vast majority of whom can be considered bilingual and who are learning English as a third language.

This will allow any future interested parties to consider the comparability of the data with other data and supports this study's generalizabilty.

\subsection{Design \& Materials}

Stage 1: Participants were given preliminary questionnaires in English to complete (see appendix) regarding their language biographies and attitudes and perceptions of linguistic similarity/distance between languages. These were administered by an English teacher and completed in the presence of the same teacher to help with any comprehension difficulties or ambiguities. A total of 50 questionnaires were completed, which were conserved by the participants and handed in at a later point in time together with the written task (see Stage 2).

Nominal data were requested in the first three questions concerning native language, English as participants' L3 and L2 proficiency (Questions 1, 2 and 3). Regarding native language, it was stressed to respondents by the administrators that they should identify their first acquired language as their L1, as opposed to the language that they have officially declared as their language of affiliation (Riehl, 2001: 15). On occasions residents tactically choose their language affiliation for the socio-economic reasons set out in section 4.1. Question 3 was designed to determine respondents' perceived or actual L2 proficiency. Ordinal data were requested in the form of a five-point Likert scale in order to account for the variety in the participants' opinions and perceptions (Question 4). Question 4 was designed to provide further insight into some of the possible reasons behind L2 transfer that 
were suggested in section 3.3. The questions (items a - j) had the following aims:

a) to investigate respondents’ perceptions of grammatical correspondence between German and English and language distance (TPM: Rothman \& Cabrelli, 2009).

b) to investigate respondents' perceptions of grammatical correspondence between Italian and English and language distance (TPM: Rothman \& Cabrelli, 2009).

c) to investigate respondents' perceptions of similarities between Italian and English lexis and language distance (TPM: Rothman \& Cabrelli, 2009).

d) to investigate respondents’ perceptions of similarities between German and English lexis and language distance (TPM: Rothman \& Cabrelli, 2009).

e) to investigate respondents' general metalinguistic awareness, which may facilitate transfer (Jessner 2006), and tendency towards “avoidance”, which may hinder it (Jessner, 2003).

f) to investigate respondents' opinions on the advantages of bilinguals in 3rd language acquisition (CEM: Flynn et al., 2004).

g) to investigate respondents' avoidance of “foreign language mode” (Selinker \& Baumgartner Cohen, 1995).

h) to investigate respondents' level of cultural identification with their L2 (Singh \& Carroll, 1979).

i) to investigate respondents' distrust of similarity between languages (Schachter, 1974).

j) to investigate respondents' association of their L2 with certain formal situations (Hammarberg, 2001).

Information on other factors possibly influencing L2 transfer was not requested. Although lexical transfer is not being examined in detail by this study, it was nonetheless included, as it plays such a major role and may shed some light on syntactic transfer. Order of acquisition was evident from Questions 1, 2 and 3, and recency of L2 use and exposure to L2 was assumed, given the context. Age was not considered a variable, as all respondents were over 18 and therefore previous research on age and L2 transfer is not relevant to this study, being based on much younger learners (Cenoz, 2001; Selinker \& Lakshmanan, 1993). Gender was not considered to have an effect on L2 transfer.

Stage 2: Participants received a medical article on the topic of malnutrition and nutritional care practices in hospital wards for older people to summarise in about 200 - 250 words. This task was not carried out under exam conditions, but either at home or in class. The article was of average length and in its original published form, i.e. not adapted for learners of English, as is the policy of the college regarding academic reading materials. It therefore contained comprehensive input (Krashen, 1982) that may in some cases have been a little beyond participants' current ability. However, the participants had on several previous occasions been given similar tasks summarising medical articles, were familiar with the techniques involved in summary writing and the use of dictionaries was permitted.

The statistics were initially analysed on a descriptive basis to make sense of the data and convert the data into information.

\subsection{Subjects}

There were 46 participants, none of whom may be described as monolingual, as B2/C1 competence is a requirement for entry to the college and is assessed during the selection procedure

(see Claudiana http://www.claudiana.bz.it/de/claudiana/unterrichtssprachen.html). Written samples were collected from students who had reached the point where they were typically "L2 users" rather than learners (Cook, 2004) and who could be said to be at various points along the language continuum (Grosjean, 1989). On an academic level, they occupy the bilingual end of the continuum, yet may find themselves at the monolingual end in their private lives (ibid.).

For the purposes of this study, and in the light of Rothman's 2011 study, which takes empirical evidence from Iverson (2009) to suggest that co-ordinate bilinguals (Weinreich, 1953) do not need to be treated separately to compound bilinguals (ibid.), the subjects were analysed as one group, regardless of their potentially differing bilingual status. Rothman states:

“... whatever variables conspire to determine which properties from previously acquired languages transfer in L3/Ln acquisition for child bilinguals would also be the same variable for adult bilinguals acquiring yet another language as an adult”. (2011: 2).

The main criteria were that their L2 competence had been attested to by means of the linguistic requirements 
at the college (B2/C1 German/Italian L2), and that they had acquired English as an L3.

Local language policy requires that English is introduced at middle school level, although some schools offer experimental English at primary school. There are five further years of English at secondary school, which all participants had completed in order to enter the college

(see http://www.provincia.bz.it/intendenza-scolastica/progetti/progeto-l3.asp). The secondary school system differentiates between linguistic, scientific, artistic and social science-related schools. Therefore L3 English competence tended to range from B1-C1 level, as some subjects would have had their first contact early in their school career or may have had more hours of English instruction at a secondary school specializing in modern languages. English language lessons at the college are an obligatory component of the curriculum, with an average of 2 hours per week of general and specialized language. The subjects were a mixture of first and second year students.

\subsection{Measurement and Justification}

Stage 1: The data from the questionnaires were analysed and cleaned according to Dörnyei's instructions for data cleaning (Dörnyei, 2010: 88-89). The questionnaires initially acted as an aid in separating the written summaries into L2 German and L2 Italian groups, but were subsequently processed as one group and no differentiation was made between L2 German and L2 Italian. Written samples from the four declared trilinguals with Ladin mother tongue were eliminated from the study, as these had not acquired English as an L3, but as an L4/Ln, and a group size of 4 was considered too small to examine. After categorizing subjects according to their declared L2, the number of samples of written English L3 production was 46. Neither age nor gender were variables in this study.

Stage 2: For the reasons set out in section 3.5, of the extensive research carried out on cross-linguistic influence, grammatical errors due to L2 transfer appear to have received attention only recently (Bardel and Falk, 2007; Flynn et al., 2004; Rothman, 2010) when compared to transfer at a lexical level (Cenoz et al., 2003; Dewaele, 1998; Ecke, 2001).

As this study is based on written data, transfer of phonological features from the L2 cannot be analysed here and would require separate study. The factors triggering transfer of phonological phenomena may also differ considerably to those relating to written production, in that L3 speakers have much less time to analyse and plan their utterances than they have when producing written text.

This study does not look at comprehension. However, participants will have needed to comprehend medical articles before writing summaries. Therefore receptive strategies are also indirectly involved.

An examination of lexical retrieval from the L2 is not a primary focus of this study of this study, although of great interest and evident in the data available. This is because the medical nature of the article to be summarised may confound the results and encourage the use of lexis deriving from Latin, which is typologically related to Italian. This may create a bias towards lexical transfer from Italian L2 in L1 German speakers and discourage L2 German interlanguage transfer in L1 Italian speakers.

Several parameters were identified from existing research and considered for their suitability in this study. Table 2 shows typological differences that have the potential to influence L2 transfer to L3 English at B2 level.

Some impetus for the examination of grammatical transfer from the L2 was provided by Croft (2003), who detailed typological differences between languages in general. Bardel and Falk (2007) and Flynn et al. (2004) conducted research focusing on specific grammatical parameters such as sentence negation and relative clauses, and Jessner's Tyrol study (2006) showed German speakers making use of compensatory strategies from their L2 Italian to produce the continuous aspect and accurate adverb use in L3 English. Similarly closely documented is the pro-drop parameter in Italian, which may lead to the omission of the subject in non-pro-drop languages according to Bardel and Falk (2007) and Kean (1986). Clyne's 1997 study on trilingual behaviour makes some interesting observations on the word order of German, Italian and English, stating that English has an SVO structure and German, despite being an SVO language in main clauses, uses SOV in subordinate clauses due to its V2 property (1997: 97). He states that, "The verb comes second, which means that when another constituent is topicalised into $1^{\text {st }}$ position, the subject follows the verb, resulting in the order $\mathrm{X}-\mathrm{V}$-subject” (ibid.). He claims that Italian, an SVO language like English, has a "more pragmatic" (ibid.), thus less grammatical, word order than English. His findings regarding language closeness are detailed in Section 6. 
This investigation is based on the hypothesis that syntactic properties present neither in participants' L1 nor L3 English, but only peculiar to their L2, may appear in their L3 production. According to this, an L1 German speaker should perform in disaccord with both German and English grammar, maintaining certain features of their L2 neither present in English nor German, and an L1 Italian speaker should perform in disaccord with both Italian and English grammar, maintaining certain features of their L2 neither present in English nor Italian. Furthermore, L2 speakers may exhibit the same types of syntactic transfer as L1 speakers, i.e. an L1 Italian speaker may make similar errors regarding the continuous aspect of verbs as an L1 German speaker, despite the fact that the continuous aspect is present in their L1 Italian and may not have "interfered” with production if German had not been previously acquired as an L2.

As English is a genetically Germanic language that has been influenced by Latin and French (Greenberg, 1974), isolating grammatical structures that are exclusive to each of the three languages was neither possible nor considered necessary within the scope of this study.

The groups were therefore divided into L1 and L2 German (Set 1) and L1 and L2 Italian (Set 2) and the samples from each group were analysed for specific cases of syntactic transfer from each language. The constraints of this study did not permit the examination and design of a realistic and practical means of identifying every instance of negative transfer governed by the parameters set out in Table 2.

A T-unit evaluation method was adopted and ratios were initially worked out, taking the T-unit as an index of measurement.

After consideration of the different parameters in Table 2, two criteria were selected for ascertainment of L1/L2 negative transfer or absence thereof:

Set 1 for German transfer (parameter 1): An examination of learners' treatment of commas before subordinate clauses.

To investigate instances of transfer from German syntax, the T-unit consisted of all main clauses containing subordinate clauses, with subordinate clauses including all adverbial, adjective, and noun clauses (non-restrictive relative clauses, where a comma would be required). The results were compared against identical errors from the L1 German transfer source and analysed. For L1/L2 German learners, inserting a comma before a subordinate clause excluding non-defining relative clauses was scored as an error.

Set 2 for Italian transfer (parameter 2): An examination of learners' treatment of pro-drop forms or the Null

\section{Subject Parameter.}

To investigate instances of L2 Italian transfer, the T-unit consisted of all main and subordinate clauses where a pronoun was required as subject. The results were compared against identical errors from the L1 Italian transfer source and analysed. For L1/L2 Italian learners, omitting the subject before a verb where it would ordinarily be required was scored as an error.

Table 2. Some typological differences between German, Italian and English adapted from the following: Croft, 2003; Jessner, 2006; Clyne, 1997; Bardel \& Falk, 2007; Kean, 1986; Odlin, 1990; Klein, 1995; Flynn et al., 2004; Rothman, 2011.

\begin{tabular}{lll}
\hline \multicolumn{1}{c}{ German } & Italian & English \\
\hline satellite-framed & verb-framed & satellite-framed \\
no adjective/adverb differentiation & adjective/adverb differentiation & adjective/adverb differentiation \\
V2 & non V2 & non pro-drop \\
non pro-drop & pro-drop & preposition-stranding \\
preposition-stranding & non preposition-stranding & no comma preceding subordinate clause, \\
except non-restrictive relative clause
\end{tabular}

* preposition stranding only occurs in German in pseudopassive sentences. 
The number of errors for each instance of negative transfer per linguistic group (Sets 1 and 2) was then calculated and processed by means of the SPSS (Statistical Package for Social Science) using two sets of independent samples. This allowed a comparison of the two groups for identical errors, with one group's errors being conditioned by L1 negative transfer and the other group’s by L2 negative transfer.

\section{Results}

As predicted, the written data provided evidence of L2 syntactic transfer from both German and Italian into English L3.

Stage 1: Participant breakdown according to Question 1 of the questionnaire is shown in Table 3. Data from the four trilingual respondents were excluded from the study, leaving 46 respondents whose L3 was English (Question 2) (see Table 3).

Respondents’ L2 competence according to their own admissions (Question 3) was shown in Figure 2.

This demonstrates increased perceived or actual competence in L2 Italian by L1 German speakers compared to L2 German by L1 Italian speakers, which could play an important role in conditioning L2 interlanguage transfer.

The responses to the points in the Likert scale in Question 3 were converted into percentages and organized into pie charts a) - j) to clearly display the participants’ responses (see Figure 3). These data indicate learners' opinion and attitudes towards language learning and English as an L3.

It is evident that respondents, regardless of their L1, perceived slightly less distance between German and English than between Italian and English in terms of grammar (Items a and b). A large number expressed that they did not know whether there were similarities, however. Interestingly, respondents were more likely to use an Italian word than a German word and hope that it is close to the target form in the event that they did not know the word in English (Items c and d). This suggests that there are greater perceived lexical similarities between English and Italian than between English and German. Respondents indicated that they had a good degree of metalinguistic awareness (Item e) and that they were aware of the fact that differences between language structures exist. There was support for the suggestion that bilinguals have an advantage over monolinguals in the acquisition of a third language and that they may draw on prior learning experience to help them (Item $\mathrm{f}$ ). The respondents clearly indicated that "sounding foreign” was to be avoided when producing English (Item g) and there was little evidence to suggest that they identified with their L2 more than their L1 (Item h). A high proportion did not know if they practised avoidance in English L3 production, yet a large number did not seem to be deterred from producing L3 structures that were similar to those in their L2 (Item i). Regarding L2 association with formal or academic contexts, the largest proportion indicated that they did not associate one language with their studies more than another (Item j), possibly due to the fact that college policy requires lectures to take place in both German and Italian languages with no bias towards one or the other.

Stage 2: An examination of learners' treatment of commas before subordinate clauses (for negative transfer from German) and pro-drop forms (for negative transfer from Italian).

Ratio measures taking the T-unit as an index of measurement:

Set 1: commas before subordinate clauses when not required: L1 German: out of 23 samples, the ratio of correct subordinate clause: subordinate clause errors per T-unit was 54:20. L2 German: out of 23 samples, the ratio of correct subordinate clause: subordinate clause errors per T-unit was 36:11.

Set 2: pro-drop form when required: L1 Italian: out of 23 samples, the ratio of correct use of pro-drop form: pro-drop form errors per T-unit was 32:7. L2 Italian: out of 23 samples, the ratio of correct use of pro-drop form: pro-drop form errors per T-unit was 41:4

These initial ratios suggest that, although more transfer errors are made due to L1 interference for each parameter investigated, there is also evidence of the same errors being made due to L2 transfer.

Table 3. L2 distribution of participants.

\begin{tabular}{cc}
\hline Italian L2 & 23 \\
German L2 & 23 \\
Trilingual & 4 \\
\hline
\end{tabular}




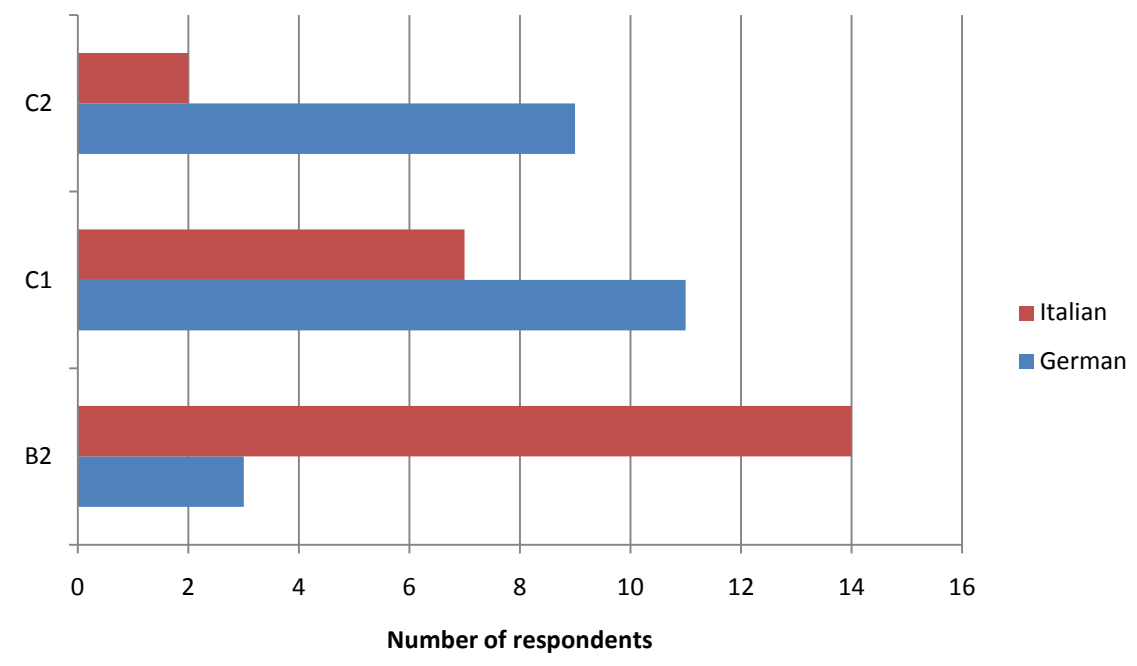

Figure 2. Participants’ L2 competence in accordance with the CEFR.
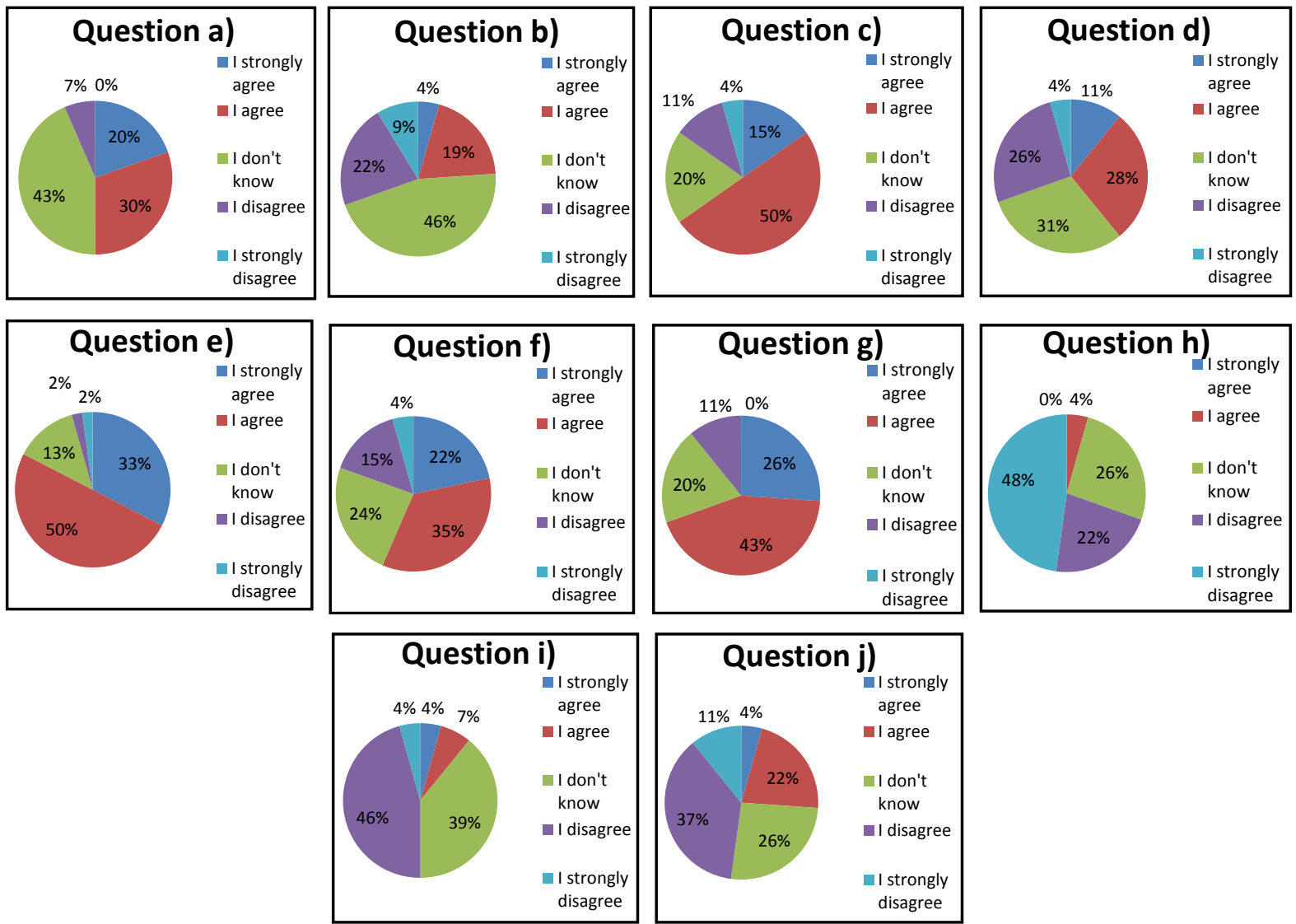

Figure 3. Responses to questionnaire items a) - j) in percentages. a) I think that German grammar is more similar to English grammar than Italian grammar; b) I think that Italian grammar is more similar to English grammar than German grammar; c) If I don't know a word I sometimes try to use the Italian word and hope that the English is similar; d) If I don't know a word I sometimes try to use the German word and hope that the English is similar; e) Speaking two languages helps me to understand that different languages use different grammatical structures; f) I think that bilingual people can use their language-learning experience to help them learn a third language; g) I don't like to sound as if I am using my native language(s) when speaking or writing English; h) I identify more strongly with my L1 than with my L2; i) I don't trust structures that are similar to structures in my L2 in English, so I don’t use them; j) I associate my L2 more than my L1 with my studies here at Claudiana. 
Independent samples tests: The results of the T-unit evaluation of the syntactic errors contained in the 46 summaries using the SPSS are illustrated in Table 4(a)-(d) \& Table 5(a)-(d).

Set 1: subordinate clause errors German/Italian (L1/L2 German transfer)

An independent samples t-test was conducted to compare the number of errors in subordinate clauses in L1 German/L2 Italian and L2 German/L1 Italian conditions.

There was not a significant difference in the scores for IV (Independent Variable) level 1 (L1 German/L2 Italian) $(\mathrm{M}=0.8696, \mathrm{SD}=1.01374)$ and IV (Independent Variable) level 2 (L2 German/L1 Italian) $(\mathrm{M}=0.4783$, $\mathrm{SD}=0.66535)$ conditions; $\mathrm{t}(44)=1.548, \mathrm{p}=0.129 / 0.130$.

These results suggest that L1 German/L2 Italian speakers do not make a significantly higher number of negative transfer errors involving subordinate clauses from German than L2 German/L1 Italian speakers, with L1 German speakers making 0.8696 errors per T-unit and L2 German speakers making 0.4783 errors.

Set 2: pro-drop parameter errors Italian/German (L1/L2 Italian transfer)

As in Set 1, an independent samples t-test was conducted to compare the number of errors involving pro-drop forms in L1 Italian/L2 German and L2 Italian/L1 German conditions.

There was not a significant difference in the scores for IV level 1 (L1 Italian/L2 German) $(\mathrm{M}=0.3043, \mathrm{SD}=$ $0.63495)$ and IV level 2 (L2 Italian/L1 German) $(\mathrm{M}=0.1739, \mathrm{SD}=0.38795)$ conditions; $\mathrm{t}(44)=0.841, \mathrm{p}=$ $0.405 / 0.406$.

These results suggest that L1 Italian/L2 German speakers do not make a significantly higher number of negative transfer errors from Italian involving pro-drop forms than L2 Italian/L1 German speakers, with L1 Italian speakers

Table 4. (a)-(d): results of SPSS analysis for Set 1. (a) Group statistics; (b) Independent samples test; (c) Independent samples test; (d) Independent samples test.

(a)

\begin{tabular}{cccccc}
\hline & IV German Italian & $\mathrm{N}$ & Mean & Std. Deviation & Std. Error Mean \\
\hline \multirow{2}{*}{ DV subclause errors } & 1.00 & 23 & 0.8696 & 1.01374 & 0.21138 \\
& 2.00 & 23 & 0.4783 & 0.66535 & 0.13873 \\
\hline
\end{tabular}

(b)

\begin{tabular}{ccccc} 
& & \multicolumn{2}{c}{ Levene's Test for Equality of Variances } & t-test for Equality of Means \\
\cline { 3 - 4 } & & F & Sig. & t \\
\hline $\begin{array}{c}\text { DV subclause } \\
\text { errors }\end{array}$ & Equal variances assumed & 3.647 & 0.063 & 1.548 \\
\hline
\end{tabular}

(c)

\begin{tabular}{ccccc}
\hline & & \multicolumn{3}{c}{ t-test for Equality of Means } \\
\cline { 3 - 4 } & & $\mathrm{df}$ & Sig. (2-tailed) & Mean Difference \\
\hline $\begin{array}{c}\text { DV subclause } \\
\text { errors }\end{array}$ & Equal variances assumed & 44 & 0.129 & 0.39130 \\
& Equal variances not assumed & 37.987 & 0.130 & 0.39130 \\
\hline
\end{tabular}

(d)

\begin{tabular}{|c|c|c|c|c|}
\hline & & \multicolumn{3}{|c|}{ t-test for Equality of Means } \\
\hline & & \multirow{2}{*}{ Std. Error Difference } & \multicolumn{2}{|c|}{ 95\% Confidence Interval of the Difference } \\
\hline & & & Lower & Upper \\
\hline \multirow{2}{*}{ DV subclause errors } & Equal variances assumed & 0.25284 & -0.11826 & 0.90087 \\
\hline & Equal variances not assumed & 0.25284 & -0.12055 & 0.90316 \\
\hline
\end{tabular}


Tables 5. (a)-(d): results of SPSS analysis for Set 2. (a) Group Statistics; (b) Independent Samples Test; (c) Independent Samples Test; (d) Independent Samples Test.

(a)

\begin{tabular}{cccccc}
\hline & IV Italian German & N & Mean & Std. Deviation & Std. Error Mean \\
\hline \multirow{2}{*}{ DV prodrop } & 1,00 & 23 & 0.3043 & 0.63495 & 0.13240 \\
& 2,00 & 23 & 0.1739 & 0.38755 & 0.08081 \\
\hline
\end{tabular}

(b)

\begin{tabular}{ccccccc}
\hline & & \multicolumn{2}{c}{ Levene's Test for Equality of Variances } & \multicolumn{3}{c}{ t-test for Equality of Means } \\
\cline { 3 - 6 } & & F & Sig. & t & df \\
\hline \multirow{2}{*}{ DV prodrop } & Equal variances assumed & 3.577 & 0.065 & 0.841 & 44 \\
& Equal variances not assumed & & & 0.841 & 36.394 \\
\hline
\end{tabular}

(c)

\begin{tabular}{ccccc} 
& & \multicolumn{3}{c}{ t-test for Equality of Means } \\
\cline { 3 - 5 } & & Sig. (2-tailed) & Mean Difference & Std. Error Difference \\
\hline \multirow{2}{*}{ DV prodrop } & Equal variances assumed & 0.405 & 0.13043 & 0.15511 \\
& Equal variances not assumed & 0.406 & 0.13043 & 0.15511 \\
\hline
\end{tabular}

(d)

\begin{tabular}{|c|c|c|c|}
\hline & & \multicolumn{2}{|c|}{ t-test for Equality of Means } \\
\hline & & \multicolumn{2}{|c|}{ 95\% Confidence Interval of the Difference } \\
\hline & & Lower & Upper \\
\hline \multirow{2}{*}{ DV prodrop } & Equal variances assumed & -0.18217 & 0.44304 \\
\hline & Equal variances not assumed & -0.18402 & 0.44489 \\
\hline
\end{tabular}

making 0.3043 errors per T-unit, and L2 German speakers making 0.1739 errors.

The fact that no significant difference could be observed between the two language groups (the Independent Variables) for both sets of tests, with the Sig. 2-tailed value (or p values) being greater than 0.05, indicates that written L3 production tends to be conditioned by L2 transfer as well as by L1 transfer, although L2 transfer features to a slightly lesser extent.

Instances of both L1 and L2 transfer were more frequent for the parameters tested in Set 1 . However, the p value was lower for Set 1 (0.129 compared with 0.405$)$, indicating that the difference between the two groups for the specific parameter investigated (German L1/L2 transfer) is greater. This suggests that syntactic transfer from L2 German is less frequent than transfer from L2 Italian for the parameters investigated.

\section{Discussion}

Contrary to Dewaele's (1998), Hakansson et al.'s (2002) and Vogel's (2005) findings, where the occurrence of L2 syntactic transfer was disputed, this study's data demonstrates a degree of cross-linguistic syntactic influence from both German L2 and Italian L2, although L2 German features to a lesser extent. The increased frequency of L2 Italian interlanguage transfer compared with L2 German contrasts with Jessner's findings in her Tyrol study regarding German and Italian-based strategies. She found $54.5 \%$ of strategies to be German-based and 23.5\% Italian-based (2006: 91). However, her study focuses on strategies to overcome linguistic deficits and emphasises facilitative transfer of both grammar and lexis rather than negative syntactic transfer, and was therefore not designed to analyse purely written production for syntactic errors, as is the case here.

One surprising finding from the Results section concerns psychotypology: despite the fact that participants tend to perceive greater syntactic similarity between German and English than between Italian and English, a decreased number of errors were made due to L2 German transfer compared to L2 Italian transfer. It appears 
that German is perceived to be similar to English on a grammatical level, but in practice this does not play as important as role as its potential suggests. This rather unexpected finding actually concords with Clyne's (1997) research on trilinguals, in which he found no examples of German and English being treated like varieties of one of the trilinguals' languages under investigation:

"...it is evident that for some of the trilinguals, two of the languages are treated like varieties of one of their languages...There are no examples of this kind linking German and English” (1997: 107).

Shedding some light on the results of this study, Clyne (ibid.) offers two continua involving several languages:

Ranked in terms of grammar:

Hungarian German Dutch English Italian/Spanish

Ranked in terms of pragmatic/grammatical word order:

Hungarian German Dutch Italian/Spanish English

Clyne suggests that convergence in microprocessing strategies "will be shared between languages that are adjacent on the above continuum" (ibid.). Therefore, according to both the grammar and pragmatic/grammatical word order continua, L2 transfer strategies involving German and English seem unlikely, yet English/Italian remains a possibility.

In her Tyrol study, Jessner does admit that L2 Italian transfer is possible, however, and states that German-speaking learners of English are able to make use of their knowledge of Italian to help them with certain grammatical forms such as aspect for continuous tenses, and adverbs and adjectives (2006: 114). Although this may sometimes be the case, there is little evidence of this in the current study, where adjectives and adverbs are frequently used incorrectly, indicating more L1 German influence than L2 Italian. There is even overproduction of continuous forms in the L2 Italian sample, as may be typical for L1 German learners of English (Swan \& Smith, 2001: 42), further indicating the non-employment of Italian L2 compensatory strategies. The identification of facilitative rather than negative L2 transfer is admittedly somewhat more problematic (Ringbom, 1986), and, without participants' own explanations for their grammatical choices in L3 production, it is difficult to ascertain whether L2 strategies have been employed or not. We can only view the results as an indication of certain decision processes during the construction of the L3 text and, as Dechert warns, these "cannot be understood as portraits of cognitive or linguistic processing” (1997: 32).

Learners' perceptions of English as a Germanic language therefore do not appear to greatly influence L2 German transfer, contrary to theories regarding psychotypology (Kellerman, 1983; Rothman, 2011). There may also be an element of unconscious L2 activation involved in the case of L2 Italian due to typological similarities that are less evident to learners. Singleton and Little claim that English features aspects that are close to German and Italian alike:

"While it is true that English is in terms of its basic grammatical structure a Germanic language, in terms of its lexis it can, thanks to 1066 and all that, plausibly be regarded as a Romance language" (Singleton and Little, cited in Jessner 2006: 78).

Pinker also suggests that English has been influenced by other, non-related languages over the centuries:

"English has changed from a free-word-order, highly inflected, topic-prominent language, as its sister German remains to this day, to a fixed-word-order, poorly inflected, subject-prominent language, all in less than a millennium...The absence of a strong correlation between the grammatical properties of languages and their place in the family tree of languages suggests that language universals are not just the properties that happened to have survived from the hypothetical mother of all languages." (1994: 235)

Therefore, although these findings are perhaps surprising in terms of perceived language typology, the potential for increased L2 Italian transfer of form due to learners' consciousness of reduced language distance still exists.

Other variables involved in this study accounting for the lower level of transfer from L2 German compared to L2 Italian, however, cannot be excluded.

Syntactic transfer of L2 German (Set 1): Although we may generally expect transfer of form to occur more frequently in languages that are seen as typologically related (De Angelis \& Selinker, 2001), it appears that the reduced L2 German transfer in this group may have been due to the counter-balancing effect of the L2 status factor. The L2 German learners in this study are typically not as proficient in German as L2 Italian learners are in Italian (see Figure 2), thus hindering possible syntactic transfer. Greater L2 proficiency is said to increase the tendency towards L2 transfer (Hammarberg, 2001), even though assessing one's own competence may be a 
subjective matter (Grosjean, 1989). It is possible that the L1 Italian/L2 German speakers in this study do not have as many L2 strategies at their disposal as the L1/L2 Italian German speakers. Another scenario is that, although L2 German learners may have been able to use L2 transfer strategies at the initial state due to German/English typological similarity (Bardel \& Falk, 2007) and consequently perceive the languages as close in terms of grammar, once past that initial stage of learning they may no longer be able to activate L2 transfer as they have not yet acquired the proficiency to attempt manipulation of German. This may result in this group occupying an in-between space in terms of access to L2 interlanguage.

Thus, these two factors of psychotypology and L2 status may work against each other when found under the same conditions, simultaneously increasing and decreasing the likelihood of L2 transfer. De Bot (in press) stresses the potential for this combination as a confounding factor and points out that:

"It is necessary to isolate the effect of these two factors, typology and L2 status, so as to know their relative influence in language activation" (cited in Cenoz, 2003: 107).

On the other hand, Rothman and Cabrelli's 2009 study suggests that language proximity and the L2 status factor may interact and support each other given the right language pairings (2009: 26-27). The data provided in this current study indicate that not only may they interact, but there can also be a counteractive effect.

A comparison of errors may be made:

Typical subordinate clause errors due to L1 German transfer.

"The results of the study showed, that in all participants the prevalence rate of malnutrition in wards for older people was 31.9\%."

"The study in this article asked concerned people, who had to adapt their homes, if they received appropriate professional support."

Typical subordinate clause errors due to L2 German transfer.

"The results show, that malnutrition was a problem for old people, because they don't eat enough in hospital."

"First of all there was made a data collection, which included the nutritional status of older people."

From these examples it is clear that, whether triggered by L1 or L2 German, identical types of errors are made in written production. However, the discrepancy between the L1/L2 error rates was greater than in Set 2, showing greater difference in transfer rates between the two groups.

Syntactic transfer of L2 Italian (Set 2): Perceived grammatical distance between Italian and English was greater than between German and English, yet L2 Italian learners displayed a similar number of pro-drop errors to L1 Italian speakers. This number was statistically more significant than the number of L2 German errors according to the independent samples analysis. Typological proximity, therefore, at least to account for syntactic transfer, does not seem to be an explanation here. The L2 proficiency and exposure of this group, on the other hand, may play a more significant role. General L2 proficiency was found to be greater, with far more L2 Italian learners claiming C2 level than L2 German learners (see Figure 2), and increased exposure is more likely due to the national context, indicating that social as well as linguistic factors may be at work. L2 Italian speakers tend to be required to switch to their L2 more frequently than L2 German speakers, as Italian is often the default language even when just one non-L1 German speaker is present. This results in increased L2 practice for this linguistic group, often to the detriment of the other group in language exposure terms. L2 Italian learners may therefore be more used to manipulating language according to the situation, which may result in increased L2 transfer in their L3 English production, whether facilitative or negative.

A comparison of errors may be made:

Typical errors due to L1 Italian pro-drop transfer.

"The result of the nutritional care was negative because reflected a low quality in care practice."

"In conclusion, the use of nutritional care practices is suboptimal in hospitals and is important to increase the consciousness of the importance of nutritional care."

Typical errors due to L2 Italian pro-drop transfer.

"Particularly focuses on the roles of the main professionals, particularly dieticians."

"Finally is to notice that nutritionists are important in this process."

From these examples it is clear that, whether triggered by L1 or L2 Italian, identical types of errors are made in written production. The discrepancy between the L1/L2 error rates was lower than for Set 1, however, showing more similar rates of transfer between the groups.

Transfer of L2 lexis: While not the main focus of this study, L2 lexical transfer was very evident. The find- 
ings from the questionnaire items c) and d) on perceived lexical proximity between both German and English and Italian and English contrast with respondents' perceived syntactic similarities between these languages, and there were more frequent instances of L2 Italian lexical transfer than L2 German lexical transfer. This may reflect learners' consciousness of shared properties between Italian and English (Clyne, 1997; Jessner 2006; Pinker, 1994), or may once more be due to the L2 status factor. According to Singleton (2003), lexical transfer occurs in the following way:

"when we encounter new languages we very quickly make judgements about their relationship to languages we already know and in processing terms exploit the lexical resources in those already established languages accordingly, prioritizing those languages which we deem to be most useful and making less use of those which we see as less relevant." (cited in Jessner, 2006: 26)

As mentioned before, L2 Italian speakers do appear to be more at ease with manipulating and exploiting their L2 Italian than L2 German speakers.

Typical examples for L2 Italian learners concern the countability of nouns where Italian uses the singular, uncountable form for nouns that are plural and countable in German and English:

"people who has recently had a home adaptation"

"This people..."

Examples of lexical inventions are: "formation" for "training”, "individuated" for "identified" and "sodisfaction" for "satisfaction", all clearly demonstrating retrieval from L2 Italian rather than L1 German.

Jessner similarly found fewer instances of German lexis finding its way into L3 English than Italian lexis. She noted that students frequently chose Italian rather than German lexical items in English L3 production and states that:

"...the high level of metalinguistic awareness of the informants and their informed background could also be an indication of the students' awareness of related words of Latin origin in Italian and English” (2006: 102).

Further explanations for syntactic transfer: As there was evidence of both L1 and L2 transfer, the Full Access/L1 transfer hypothesis, which maintains that transfer is exclusively the preserve of L1 influence, may not account for all the findings. Other factors affecting L2 transfer to consider may be excluded thanks to the questionnaire responses and negative transfer focus of the study. The CEM accommodates only facilitative or neutral transfer and so does not apply in this case. Likewise excluded was the Parasitic Model (Hall \& Ecke, 2003), which accounts for lexical transfer only and not syntactic transfer. Order of acquisition was the same for both groups, with English as an L3 and German or Italian as an L2. Learners did not overwhelmingly report any distrust of certain structural similarities between their languages, so the possibility of Schachter's (1974) notion of avoidance leading to underproduction and reduced transfer is negligible for both groups. Respondents tended not to identify with their L2 more than their L1, so cultural identification should not be a factor, and they did not associate their studies more with one language than the other, which may otherwise have influenced their choice of transfer language when summarising an academic text. Concerning "foreign language mode" (Selinker \& Baumgartner Cohen, 1995), the vast majority stated that they did not want to sound "foreign" when using English, which may encourage L2 interlanguage activation. However, as this opinion is likely to be often more expressed regarding spoken rather than written language (Hammarberg, 2001), it would be difficult to draw any conclusions from written samples without further qualitative research into participants' attitudes and thought processes.

Contextual reasons in addition to learner- or language-related reasons: The comparative difficulty of acquiring German compared to Italian, particularly in a geographical area where non-standard German is spoken and where there is reduced exposure to the standard language, may additionally result in a form of mental block for Italian speakers. This linguistic group, despite having achieved B2 level German, may be reluctant to engage L2 strategies in L3 production. L1 German speakers, on the other hand, may be less inclined to separate the two languages and therefore employ their L2 in a strategic manner both lexically and syntactically.

Possible limitations and constraints: There were a few factors that may have affected the outcome of the data analysis. Primarily concerning lexical L2 transfer, there may have been a confounding variable in the form of the medical nature of the summary text, as mentioned in section 4.4,. This may encourage L2 Italian retrieval and reduce the incidence of L2 German lexical retrieval, as many medical terms derive from Latin This may result in the tendency to activate Latin-related vocabulary (i.e. Italian) being stronger in L1 German speakers than the tendency to activate German-based vocabulary in L1 Italian speakers. Whether this may also have an effect on L2 syntactic transfer as well as lexical transfer cannot be predicted without further research. That having 
been said, participants did not consciously state that they associated one language more than another with their studies.

Italian L2 transfer may have been further facilitated by the existence of a very widespread local southern Bavarian-based dialect used by the L1 German population that has absorbed many Italianisms over the years (Jessner, 2006; Moser, 1982). However, these tend to take the form of loan words and have not been found to affect structure (Treffers-Dallers \& Willemyns, 2002) and should not affect transfer of the non-pro-drop parameter under examination, which is also a feature of the dialect.

For a quantitative study, the sample size could have been greater. However, a total of 46 participants was considered adequate for achieving generalizability in this particular case.

An additional, though unlikely, consideration may be that, in the case of subordinate clause punctuation, the L2 German learners did not have full control of placement of commas in their L1 Italian, resulting in their choices of comma insertion being not necessarily L2-influenced.

Future trends and practical implications: English has established itself as a lingua franca or "vehicle of communication" (Hoffmann, 2000: 2) that is more and more often acquired within the context of tri- or multilingualism. Clyne states:

"Trilingualism is likely to gain in prominence due to the exigencies of globalization, which will encourage people to have their first language, another language of significance in the region, and an international language.” (1997: 95-96).

The world's population becoming more mobile and the number of multilingual families with children learning English as an L3 increasing (Jessner, 2006: 26) inevitably gives rise to questions concerning the teaching of L3 English at schools and at higher education institutions such as:

-should teachers be competent in their learners' L2 as well as their L1?

-to what extent should teachers be aware of the influence of learners' L2 on L3 production and be able to identify and resolve L2-related errors and should this awareness be included in teachers training programmes for specific linguistic contexts?

-should native speaker teachers have already experienced language learning in order to pass on this knowledge?

-should teachers treat the teaching of L3 English differently to the teaching of L2 English?

Jessner stresses that institutions should be aware of the linguistic backgrounds of students (2006: 137) and that teachers should be "experts on multilingualism, even if they teach only one language" (2008: 45). She advocates taking advantage of learners' metalinguistic awareness by:

"enhancing the connections between the languages in both teachers and learners; that is, bridging the languages, creating synergies and exploiting resources.” (ibid.: 38).

She additionally argues that teaching English as an L3 is not the same as teaching English as an L2 due to the altered cognitive processes experienced by multilinguals (2006: 136).

However, a workable approach to teaching taking into account L2-related transfer in multilingual learners, although desirable, may not always be realistic, and some researchers may not consider it necessary. Bouvy plays down the significance of focusing on cross-linguistic transfer errors in teaching and, after finding just $5 \%$ of errors to be due to negative L2 transfer in her study of exam papers and translation exercises in L1 French business students studying a second Germanic language, concludes that:

"...cross-linguistic transfer errors do not have important teaching implications and can in fact be seen as a necessary by-product of multilingual education.” (2000: 155-156).

The languages involved in Bouvy's study are L1 French, L2 English and either L3 German or Dutch. Seen from a psychotypological perspective, this specific combination is similar to this study's L1 Italian, L2 German and L3 English combination, but less similar to the L1 German, L2 Italian and L3 English combination, where evidence of L2 transfer was higher. It may be reasonable to expect the incidence of transfer to differ depending on the particular language combinations involved and not always yield a rate as low as $5 \%$.

As research on cross-linguistic influence and language processing in multilinguals appears to be gaining in importance, it becomes inevitable that the practical implications for classrooms will have to be addressed and the extent to which relevant findings should be incorporated into the curriculum established.

\section{Conclusions}

This study provides evidence to suggest that syntactic transfer from learners' L2 does take place, yet it is per- 
haps too complex to be attributed to one factor alone. As previous research suggests, psychotypology and L2 status appear to be the main determiners of negative L2 transfer, but the findings of this study indicate that under certain conditions they may interact with or even override each other, thus increasing and reducing the potential for transfer at the same time. Extended to apply to L3 written production, the Multiple Effects Principle (Selinker \& Lakshmanan, 1993) may explain this phenomenon. Ideally, teachers would know their learners’ L1, L2 and L3. However, as this is often not the case, it is important for educators to realise that, while multilingual learners of English L3 may have an advantage over monolingual learners due to their increased metalinguistic awareness and opportunities for facilitative transfer, they may also make errors triggered by L2 transfer. Factors relating to the local context are to be taken into account as well as language- and learner-based variables. As with all studies based on a sample from a particular community, it is important to consider the implications of the specific social conditions involved before generalizing the findings and applying them to multilingual communities elsewhere.

A study involving less typologically close languages may reveal more clear-cut findings. As previously suggested by researchers (Ringbom, 2001; Vogel, 1992), the inclusion of a non-Indo European L1/L2 language may produce more decisive results regarding perceived L1/L2 and L3 language distance. This may reduce any ambiguity as to whether negative transfer is conditioned by L2 status or perceived linguistic similarities. Leung (2009) has suggested that L3 acquisition may be of great interest to generative linguists and that more research is needed into combined L3 syntax and semantics. Another more extensive study investigating more than two L2 syntactic transfer parameters would also be of value in the field of cross-linguistic influence. Within the European, and specifically L3 English, context, the fact that: "Both Germanic and Romance elements form an important part of the English language and, therefore, should not be ignored in English language teaching" (Jessner, 2008: 40) invites an examination of facilitative transfer based on similarities between languages in the classroom in order to further exploit the considerable and unique linguistic knowledge of multilinguals.

\section{References}

Alcock, A. (1992). The Protection of Regional Cultural Minorities and the Process of European Integration: The Example of South Tyrol. International Relations, 11, 17-36. http://dx.doi.org/10.1177/004711789201100102

Alcock, A. (2001). The South Tyrol Autonomy. A Short Introduction. (unpublished). http://www.provinz.bz.it/lpa/autonomy/South-Tyrol\%20Autonomy.pdf

Aronin, L., \& Hufeisen, B. (2009). The Exploration of Multilingualism: Development of Research on L3, Multilingualism and Multiple Language Acquisition. AILA Applied Linguistics Series 6. Amsterdam/Philadelphia: Benjamins. http://dx.doi.org/10.1075/aals.6

Baker, C. (2001). Foundations of Bilingualism and Bilingual Education. Clevedon: Multilingual Matter.

Bardel, C., \& Falk, Y. (2007). The Role of the Second Language in Third Language Acquisition: The Case of Germanic Syntax. Second Language Research, 23, 459-484. http://dx.doi.org/10.1177/0267658307080557

Bardel, C., \& Falk, Y. (2011). Object Pronouns in German L3 Syntax: Evidence for the L2 Status Factor. Second Language Learning, 27, 59-82.

Bassetti, B. (2007). Bilingualism and Thought: Grammatical Gender and Concepts of Objects in Italian-German Bilingual Children. International Journal of Bilingualism, 11, 251-273. http://dx.doi.org/10.1177/13670069070110030101

Benvenuto, O. (2010). South Tyrol in Figures. Bolzano: Autonomous Province of South Tyrol Provincial Statistics InstituteASTAT.

Bialystok, E. (1993). Metalinguistic Dimensions of Bilingual Language Proficiency. In E. Bialystok (Ed.), Language Processing in Bilingual Children (pp. 113-140). Cambridge: Cambridge University Press.

Bialystok, E., Craik, F., Klein, R., \& Viswanathan, M. (2004). Bilingualism, Aging, and Cognitive Control: Evidence from the Simon Task. Psychology and Aging, 19, 290-303. http://dx.doi.org/10.1037/0882-7974.19.2.290

Bloomfield, L. (1933). Language. Revised from 1914 Edition. New York: Holt.

Bouvy, C. (2000). Towards the Construction of a Theory of Cross-Linguistic Transfer. In J. Cenoz, \& U. Jessner (Eds.), English in Europe: The Acquisition of a Third Language (pp. 143-156). Clevedon: Multilingual Matters.

Cenoz, J. (2003). The Role of Typology in the Organization of the Multilingual Lexicon. In J. Cenoz, B. Hufeisen, \& U. Jessner (Eds.), The Multilingual Lexicon (pp. 103-166). Dordrecht: Kluwer. http://dx.doi.org/10.1007/978-0-306-48367-7 8

Cenoz, J., Hufeisen, B., \& Jessner, U. (2003). Why Investigate the Multilingual Lexicon? In J. Cenoz, B. Hufeisen, \& U. 
Jessner (Eds.), The Multilingual Lexicon (pp. 1-10). Dordrecht: Kluwer. http://dx.doi.org/10.1007/b101932

Chamot, A. (1973). Phonological Problems in Learning English as a Third Language. International Review of Applied Linguistics, 11, 243-250.

Chomsky, N. (1957). Syntactic Structures. The Hague: Mouton.

Clyne, M. (1997). Some of the Things Trilinguals Do. The International Journal of Bilingualism, 1, 95-116.

Clyne, M. (2003). Dynamics of Language Contact. Cambridge: Cambridge University Press. http://dx.doi.org/10.1017/CBO9780511606526

Cohen, A. D. (1995). In Which Language Do/Should Multilinguals Think? Language, Culture and Curriculum, 8, 99-113. http://dx.doi.org/10.1080/07908319509525194

Cook, V. (1992). Evidence for Multicompetence. Language Learning, 42, 557-591. http://dx.doi.org/10.1111/j.1467-1770.1992.tb01044.x

Cook, V. (2005). Multicompetence: Black Hole or Worm Hole?

http://homepage.ntlworld.com/vivian.c/Writings/Papers/SLRF05.htm

Corder, P. (1967). The Significance of Learner Errors. International Review of Applied Linguistics, 5, 161-170. http://dx.doi.org/10.1515/iral.1967.5.1-4.161

Croft, W. (2003). Typology and Universals (2nd ed.). Cambridge: Cambridge University Press.

Crystal, D. (1997). A Dictionary of Linguistics and Phonetics (4th ed.). Malden, MA/Oxford: Blackwell.

Cummins, J. (1976). The Influence of Bilingualism on Cognitive Growth: A Synthesis of Research Findings and Explanatory Hypotheses. Working Papers on Bilingualism No. 9, 1-43.

Cummins, J. (1991). Language Learning and Bilingualism. Sophia Linguistica, 29, 1-194.

De Angelis, G. (2007). Third or Additional Language Acquisition. Clevedon: Multilingual Matters.

De Angelis, G., \& Selinker, L. (2001). Interlanguage Transfer and Competing Linguistic Systems in the Multilingual Mind. In J. Cenoz, B. Hufeisen, \& U. Jessner (Eds.), Cross-Linguistic Influence in Third Language Acquisition: Psycholinguistic Perspectives (pp. 42-58). Clevedon: Multilingual Matters.

De Bot, K. (1992). A Bilingual Production Model: Levelt’s ‘Speaking’ Model Adapted. Applied Linguistics, 13, 1-24.

De Bot, K. (forthcoming). The Psycholinguistics of Multilingualism. Amsterdam/Philadelphia: Benjamins.

Dechert, H. W. (1997). Metakognition und Zweitspracherwerb. In U. Rampillon, \& G. Zimmermann (Eds.), Strategien und Techniken beim Erwerb fremder Sprachen (pp. 10-32). München: Hüber.

Dewaele, J. M. (1998). Lexical Inventions: French Interlanguage as L2 versus L3. Applied Linguistics, 19, 471-490. http://dx.doi.org/10.1093/applin/19.4.471

Dewaele, J. M. (2001). Activation or Inhibition? The Interaction of L1, L2 and L3 on the Language Mode Continuum. In J. Cenoz, B. Hufeisen, \& U. Jessner (Eds.), Cross-Linguistic Influence in Third Language Acquisition: Psycholinguistic Perspectives (pp. 42-48). Clevedon: Multilingual Matters.

Dörnyei, Z. (2010). Questionnaires in Second Language Research: Construction, Administration, and Processing (2nd ed.). New York: Routledge.

Ecke, P. (2001). Lexical Retrieval in a Third Language: Evidence from Errors and Tip-of-the-Tongue States. In J. Cenoz, B. Hufeisen, \& U. Jessner (Eds.), Cross-Linguistic Influence in Third Language Acquisition: Psycholinguistic Perspectives (pp. 90-114). Clevedon: Multilingual Matters.

Eckman, F. R. (1977). Markedness and the Contrastive Analysis Hypothesis. Language Learning, 27, 315-330. http://dx.doi.org/10.1111/j.1467-1770.1977.tb00124.x

Ellis, N. (1994). Psychological Perspectives on the Role of Conscious Processes in Vocabulary Acquisition. International Association of Applied Linguistics Review, 11, 37-56.

Ellis, R. (1997). Second Language Acquisition. Oxford: Oxford University Press.

Faerch, C., \& Kasper, G. (1986). Cognitive Dimensions of Language Transfer. In E. Kellerman, \& M. Sharwood Smith (Eds.), Crosslinguistic Influence in Second Language Acquisition (pp. 49-65). New York: Pergamon Press.

Flynn, S., Foley, C., \& Vinnitskaya, I. (2004). The Cumulative-Enhancement Model of Language Acquisition: Comparing Adults' and Children's Patterns of Development in First, Second and Third Language Acquisition of Relative Clauses. International Journal of Multilingualism, 1, 3-16. http://dx.doi.org/10.1080/14790710408668175

Fries, C. C. (1945). Teaching and Learning English as a Foreign Language. Ann Arbor: University of Michigan Press.

Green, D. (1986). Control, Activation and Resource: A Framework and a Model for the Control of Speech in Bilinguals. Brain and Language, 27, 210-223. http://dx.doi.org/10.1016/0093-934X(86)90016-7 
Greenberg, J. (1974). Language Typology: A Historical and Analytic Overview. The Hague: Mouton.

Grosjean, F. (1989). Neurolinguists, Beware! The Bilingual Is Not Two Monolinguals in One Person. Brain and Language, 36, 3-15. http://dx.doi.org/10.1016/0093-934X(89)90048-5

Grosjean, F. (2001). The Bilingual’s Language Modes. In J. Nicol (Ed.), One Mind, Two Languages: Bilingual Language Processing (pp. 1-25). Oxford: Blackwell.

Hakansson, G., Pienemann, M., \& Sayheli, S. (2002). Transfer and Typological Proximity in the Context of Second Language Processing. Second Language Research, 18, 250-273. http://dx.doi.org/10.1191/0267658302sr2060a

Hall, C., \& Ecke, P. (2003). Parasitism as a Default Mechanism in L3 Vocabulary Learning. In J. Cenoz, B. Hufeisen, \& U. Jessner (Eds.), The Multilingual Lexicon (pp. 71-85). Dordrecht: Kluwer.

Hammarberg, B (2001). Roles of L1 and L2 in L3 Production and Acquisition. In J. Cenoz, B. Hufeisen, \& U. Jessner (Eds.), Cross-Linguistic Influence in Third Language Acquisition: Psycholinguistic Perspectives (pp. 21-41). Clevedon: Multilingual Matters.

Haugen, E. (1956). Bilingualism in the Americas. Alabama: American Dialect Society.

Herdina, P., \& Jessner, U. (2000). The Dynamics of Third Language Acquisition. In J. Cenoz, \& U. Jessner (Eds.), English in Europe: The Acquisition of a Third Language (pp. 84-98). Clevedon: Multilingual Matters.

Hoffmann, C. (2000). The Spread of English and the Growth of Multilingualism with English in Europe. In J. Cenoz, \& U. Jessner (Eds.), English in Europe: The Acquisition of a Third Language (pp. 1-21). Clevedon: Multilingual Matters.

Holmes, J. (2008). An Introduction to Sociolinguistics (3rd ed.). Harlow: Pearson Education Ltd.

Hufeisen, B. (1993). Fehleranalyse: Englisch als L2 und Deutsch als L3. International Review of Applied Linguistics, 31, 242-256.

Hufeisen, B. (1998). L3-Stand der Forschung-Was bleibt zu tun? In B. Hufeisen, \& B. Lindemann (Eds.), Tertiärsprachen. Teorien, Modelle, Methoden (pp. 169-183). Tübingen: Stauffenberg.

Hufeisen, B., \& Fouser, R. J. (2005). Introductory Readings in L3. Tübingen: Stauffenburg.

Iverson, M. (2009). Competing SLA hypotheses Assessed: Comparing Heritage and Successive Spanish Bilinguals of L3 Brazilian Portuguese. In H. Pires, \& J. Rothman (Eds.), Minimalist Inquiries into Child and Adult Language Acquisition: Case Studies across Portuguese (pp. 221-244). Berlin/New York: Mouton De Gruyter.

Jessner, U. (2003). The Nature of Cross-Linguistic Interaction in the Multilingual System. In J. Cenoz, B. Hufeisen, \& U. Jessner (Eds.), The Multilingual Lexicon (pp. 45-56). Dordrecht: Kluwer. http://dx.doi.org/10.1007/978-0-306-48367-7_4

Jessner, U. (2006). Linguistic Awareness in Multilinguals. Edinburgh: Edinburgh University Press Ltd. http://dx.doi.org/10.3366/edinburgh/9780748619139.001.0001

Jessner, U. (2008). Teaching Third Languages: Findings, Trends and Challenges. Language Teaching, 41, 15-56. http://dx.doi.org/10.1017/S0261444807004739

Kean, M. L. (1986). Core Issues in Transfer. In E. Kellerman, \& M. Sharwood (Eds.), Cross-Linguistic Influence in Second Language Acquisition. New York: Pergamon Press. http://revistas.udistrital.edu.co/ojs/index.php/calj/article/view/97

Kellerman, E. (1983). Now You See It, Now You Don't. In S. Gass, \& L. Selinker (Eds.), Language Transfer in Language Learning (pp. 112-134). Rowley, MA: Newbury House.

Kellerman, E. (1995). Cross-Linguistic Influence: Transfer to Nowhere? Cambridge University Press, Cambridge, Annual Review of Applied Linguistics, 15, 125-150.

Klein, E. (1995). Second Versus Third Language Acquisition: Is There a Difference? Language Learning, 45, 419-465. http://dx.doi.org/10.1111/j.1467-1770.1995.tb00448.x

Krashen, S. D. (1982). Principles and Practices in SLA. Oxford: Pergamon Press.

Lado, R. (1957). Linguistics across Cultures. Ann Arbor: University of Michigan Press.

Leung, Y. K. (2009). Third Language Acquisition and Universal Grammar. Clevedon: Multilingual Matters.

Levelt, W. J. M. (1989). Speaking: From Intention to Articulation. Cambridge, MA: MIT Press.

Magiste, E. (1984). Learning a Third Language. Journal of Multilingual and Multicultural Development, 5, 415-421. http://dx.doi.org/10.1080/01434632.1984.9994170

Mansour, G. (1993). Multilingualism and Nation Building. Clevedon: Multilingual Matters.

Meisel, J. (1983). Transfer as a Second Language Strategy. Language and Communication, 3, 11-46.

Mikes, T. (2010). Inclusive Minority Governance in Finland, South Tirol and Slovakia. The Annual of Language \& Politics and Politics of Identity, 4, 59-74.

Missler, B. (1999). Fremdsprachenlernerfahrungen und Lernstrategien: Eine empirische Untersuchung. Tübingen: Stauffenberg. 
Moser, H. (1982). Zur Situation des Deutschen in Sudtirol. Sprachwissenschaftliche Beitrage zu den Fragen von Sprachnorm und Sprachkontakt. Innsbruck.

Murphy, S. (2003). Second Language Transfer during L3 Acquisition. Working Papers in TESOL, Applied Linguistics, 3, 1-21.

Odlin, T. (1989). Language Transfer: Cross-Linguistic Influence in Language Learning. Cambridge: Cambridge University Press. http://dx.doi.org/10.1017/CBO9781139524537

Odlin, T. (1990). Word Order Transfer, Metalinguistic Awareness, and Constraints on Foreign Language Learning. In W. Patten, \& J. Lee (Eds.), Second Language Acquisition/Foreign Language Learning (pp. 95-117). Clevedon: Multilingual Matters.

Ò Laoire, M., \& Aronin, L. (2004). Exploring Multilingualism in Cultural Contexts: Towards a Notion of Multilinguality. In C. Hoffmann, \& J. Ytsma (Eds.), Trilingualism in Family, School and Community (pp. 11-29). Clevedon: Multilingual Matters.

Paradis, M. (1987). The Assessment of Bilingual Aphasia. Hillsdale: Erlbaum.

Pienemann, M. (1984). Psychological Constraints on the Teachability of Languages. Studies in Second Language Acquisition, 6, 186-214. http://dx.doi.org/10.1017/S0272263100005015

Pienemann, M. (1998). Language Processing and Second Language Development: Processability Theory. Amsterdam: Benjamins. http://dx.doi.org/10.1075/sibil.15

Pinker, S. (1994). The Language Instinct. London: Penguin.

Poplack, S. (1980). Sometimes I'll Start a Sentence in Spanish Y Termino en español: Toward a Typology of Code-Switching. Linguistics, 18, 581-618. http://dx.doi.org/10.1515/ling.1980.18.7-8.581

Ridley, J., \& Singleton, D. (1995). Contrastivity and Individual Learner Contrasts. Fremdsprachen Lernen und Lehren, 24, 123-137.

Riehl, C. (2001). Schreiben, Text und Mehrsprachigkeit: Zur Textproduktion in mehrsprachigen Gesellschaften am Beispiel der deutschsprachigen Minderheiten in Sädtirol und Ostbelgien. Tübingen: Stauffenberg.

Ringbom, H. (1986). Crosslinguistic Influence and the Foreign Language Learning Process. In E. Kellerman, \& M. Sharwood Smith (Eds.), Crosslinguistic Influence in Second Language Acquisition (pp. 150-162). New York: Pergamon Press.

Ringbom, H. (1987). The Role of L1 in Foreign Language Learning. Clevedon: Multilingual Matters.

Ringbom, H. (2001). Lexical Transfer in L3 Production. In J. Cenoz, B. Hufeisen, \& U. Jessner (Eds.), Cross-Linguistic Influence in Third Language Acquisition: Psycholinguistic Perspectives (pp. 59-68). Clevedon: Multilingual Matters.

Ringbom, H. (2005). L2-Transfer in Third Language Acquisition. In B. Hufeisen, \& R. J. Fouser (Eds.), Introductory Readings in L3 (pp. 71-82). Tübingen: Stauffenburg Verlag.

Romaine, S. (1995). Bilingualism. Blackwell: Oxford.

Rosenberg, M. (1996). Raising Bilingual Children. The Internet TESL Journal, II.

Rothman, J., \& Cabrelli, J. (2009). What Variables Condition Syntactic Transfer? A Look at the L3 Initial State. Second Language Research, 25, 1-30.

Rothman, J. (2010). On the Typological Economy of Syntactic Transfer: Word Order and High/Low Attachment Preference in Relative Clause Interpretations in L3 Brazilian Portuguese. (In Review) International Review of Applied Linguistics, 48, 245-273.

Rothman, J. (2011). L3 Syntactic Transfer Selectivity and Typological Determinacy: The Typological Primacy Model. Second Language Research, 27, 107-127. http://dx.doi.org/10.1177/0267658310386439

Safont Jordà, M. P. (1995). Third Language Learners: Pragmatic Production and Awareness. Clevedon: Multilingual Matters.

Sagasta Errasti, M. P. (2003). Acquiring Writing Skills in a Third Language: The Positive Effects of Bilingualism. The International Journal of Bilingualism, 7, 27-42. http://dx.doi.org/10.1177/13670069030070010301

Schachter, J. (1974). An Error in Error Analysis. Language Learning, 24, 205-214.

http://dx.doi.org/10.1111/j.1467-1770.1974.tb00502.x

Schmid, S. (1996). Multilingualer Fremdsprachunterricht: Ein didaktischer Versuch mit Lernstrategien. Multilingua, 15, 5590. http://dx.doi.org/10.1515/mult.1996.15.1.55

Schwartz, B. D., \& Sprouse, R. A. (1996). L2 Cognitive States and the Full Transfer/Full Access Model. Second Language Research, 12, 40-72. http://dx.doi.org/10.1177/026765839601200103

Selinker, L. (1972). Interlanguage. Product Information International Review of Applied Linguistics in Language Teaching, 
10, 209-241. http://dx.doi.org/10.1515/iral.1972.10.1-4.209

Selinker, L., \& Baumgartner Cohen, B. (1995). Multiple Language Acquisition: ‘Damn It, Why Can’t I Keep These Two Languages Apart’. Language, Culture and Curriculum, 8, 115-121. http://dx.doi.org/10.1080/07908319509525195

Selinker, L., \& Lakshmanan, U. (1993). Language Transfer and Fossilization: The Multiple Effects Principle. In S. Gass, \& L. Selinker (Eds.), Language Transfer in Language Learning (Rev. ed., pp. 197-216). Philadelphia: Benjamins.

Shanon, B. (1991). Faulty Language Selection in Polyglots. Language and Cognitive Processes, 6, 339-350. http://dx.doi.org/10.1080/01690969108406947

Sharwood Smith, M., \& Kellerman, E. (1986). Crosslinguistic Influence in Second Language Acquisition. New York: Pergamon Press.

Shibatani, M., \& Bynon, T. (1995). Approaches to Language Typology. Oxford: Clarendon Press.

Sikogukira, M. (1993). Influence of Languages other than the L1 on a Foreign Language: A Case of Transfer from L2 to L3. Edinburgh Working Papers, Applied Linguistics, 4, 110-132.

Singh, R., \& Carroll, S. (1979). L1, L2, and L3. Indian Journal of Applied Linguistics, 5, 51-63.

Singleton, D. (2003). Perspectives on the Multilingual Lexicon: A Critical Synthesis. In J. Cenoz, B. Hufeisen, \& U. Jessner (Eds.), The Multilingual Lexicon (pp. 167-176). Dordrecht: Kluwer. http://dx.doi.org/10.1007/978-0-306-48367-7_12

Swan, M., \& Smith, B. (2001). Learner English. Cambridge: Cambridge University Press. http://dx.doi.org/10.1017/CBO9780511667121

Thomas, J. (1988). The Role Played by Metalinguistic Awareness in Second and Third Language Learning. Journal of Multilingual and Multicultural Development, 9, 235-246. http://dx.doi.org/10.1080/01434632.1988.9994334

Treffers-Daller, J., \& Willemyns, R. (2002). Language Contact at the Romance-Germanic Language Border. Clevedon: Multilingual Matters.

Vildomec, V. (1963). Multilingualism. Netherlands: A.W. Sythoff-Leyden.

Vogel, T. (1992). English und Deutsch gibt es immer Krieg. Sprachverarbeitungprozesse beim Erwerb des Deutschen als Drittsprache. Zielsprache Deutsch, 23, 95-99.

Vogel, T. (2005). German and English, They're always Fighting. Language Assimilation Process in the Acquisition of German as a Third Language. Tübingen: Stauffenberg.

Vogel, S., Maurer, O., Wytrzens, H. K., \& Larcher, M (2007). Perceptions of Mountain Farming in South Tyrol: Cultural Differences in a Border Region. In J. Kabrda, \& I. Bicik (Eds.), Man in the Landscape across Frontiers: Landscape and Land Use Change in Central European Border Regions, Conference Proceedings of the IGU/LUCC Central Europe Conference 2007, Slovenia-Austria-Slovakia-Czech Republic, Prague, Charles University, 28 August-4 September 2007, 209-220.

Weinreich, U. (1953). Languages in Contact. The Hague: Mouton.

Williams, S., \& Hammarberg, B. (1998). Language Switches in L3 Production: Implications for a Polyglot Speaking Model. Applied Linguistics, 19, 295-333. http://dx.doi.org/10.1093/applin/19.3.295

ZhaoHong, H. (2004). Fossilization in Adult Second Language Acquisition. Clevedon: Multilingual Matters.

Zobl, H. (1992). Prior Linguistic Knowledge and the Conservatism of the Learning Procedure: Grammaticality Judgements of Unilingual and Multilingual Learners. In S. Gass, \& L. Selinker (Eds.), Language Transfer in Language Learning (pp. 176-196). Rowley, MA: Newbury House. http://dx.doi.org/10.1075/lald.5.12zob 


\section{Appendix}

\section{Questionnaire}

Dear student,

Please help me to conduct some research on your attitudes and beliefs about languages and your experience of learning English as an L3. All data will be used for academic purposes only. If you want to read the results of this research or if you have any other questions, please contact me at hforsyth@gmail.com. Thank you

Helen Forsyth

1. What is/are your native language(s)? Mark with a cross $X$ in the box provided:
German $\square$
Italian $\square$
Ladin $\square$
other $\square$
I am bi-/trilingual $\square$

2. Are you learning English as a third language? $\quad$ yes $\square \quad$ no $\square$

3. Mark your $L 2$ level with a cross against just one language:
Italian
B2 $\square$
$\mathrm{C} 1 \square \quad \mathrm{C} 2 \square$
German
B2 $\square$
$\mathrm{C} 1 \square \quad \mathrm{C} 2 \square$

\section{What is your opinion? Put an $X$ next to your reaction to the following statements:}

e.g. I like chocolate

I strongly agree $\mathbf{X} \quad$ I agree I don’t know $\quad$ I disagree $\quad$ I strongly disagree

a) I think that German grammar is more similar to English grammar than Italian grammar.

I strongly agree I agree I don't know I disagree I strongly disagree

b) I think that Italian grammar is more similar to English grammar than German grammar.

I strongly agree I agree I don't know I disagree I strongly disagree

c) If I don't know a word I sometimes try to use the Italian word and hope that the English is similar.

I strongly agree I agree I don't know I disagree I strongly disagree

d) If I don't know a word I sometimes try to use the German word and hope that the English is similar.

I strongly agree I agree I don't know I disagree I strongly disagree

e) Speaking two languages helps me to understand that different languages use different grammatical structures.

I strongly agree I agree I don't know I disagree I strongly disagree

f) I think that bilingual people can use their language-learning experience to help them learn a third language.

I strongly agree I I agree I don’t know I disagree $\quad$ I strongly disagree

g) I don't like to sound as if I am using my native language (s) when speaking or writing English.

I strongly agree I agree I don't know $\quad$ I disagree I strongly disagree

h) I identify more strongly with my L1 than with my L2.

I strongly agree I agree I don't know I disagree I strongly disagree

i) I don't trust structures that are similar to structures in my L2 in English, so I don't use them.

I strongly agree I agree I don't know I disagree I strongly disagree

j) I associate my L2 more than my L1 with my studies here at Claudiana.

I strongly agree I agree I don't know I disagree I strongly disagree 
Scientific Research Publishing (SCIRP) is one of the largest Open Access journal publishers. It is currently publishing more than 200 open access, online, peer-reviewed journals covering a wide range of academic disciplines. SCIRP serves the worldwide academic communities and contributes to the progress and application of science with its publication.

Other selected journals from SCIRP are listed as below. Submit your manuscript to us via either submit@scirp.org or Online Submission Portal.
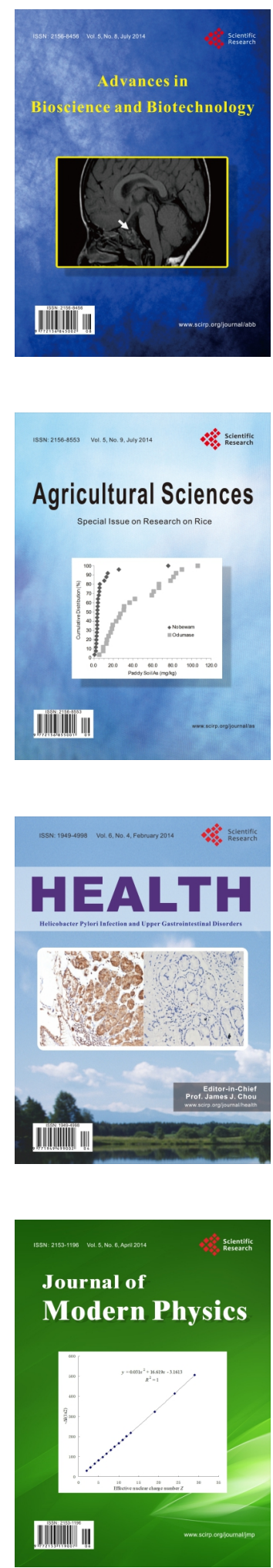
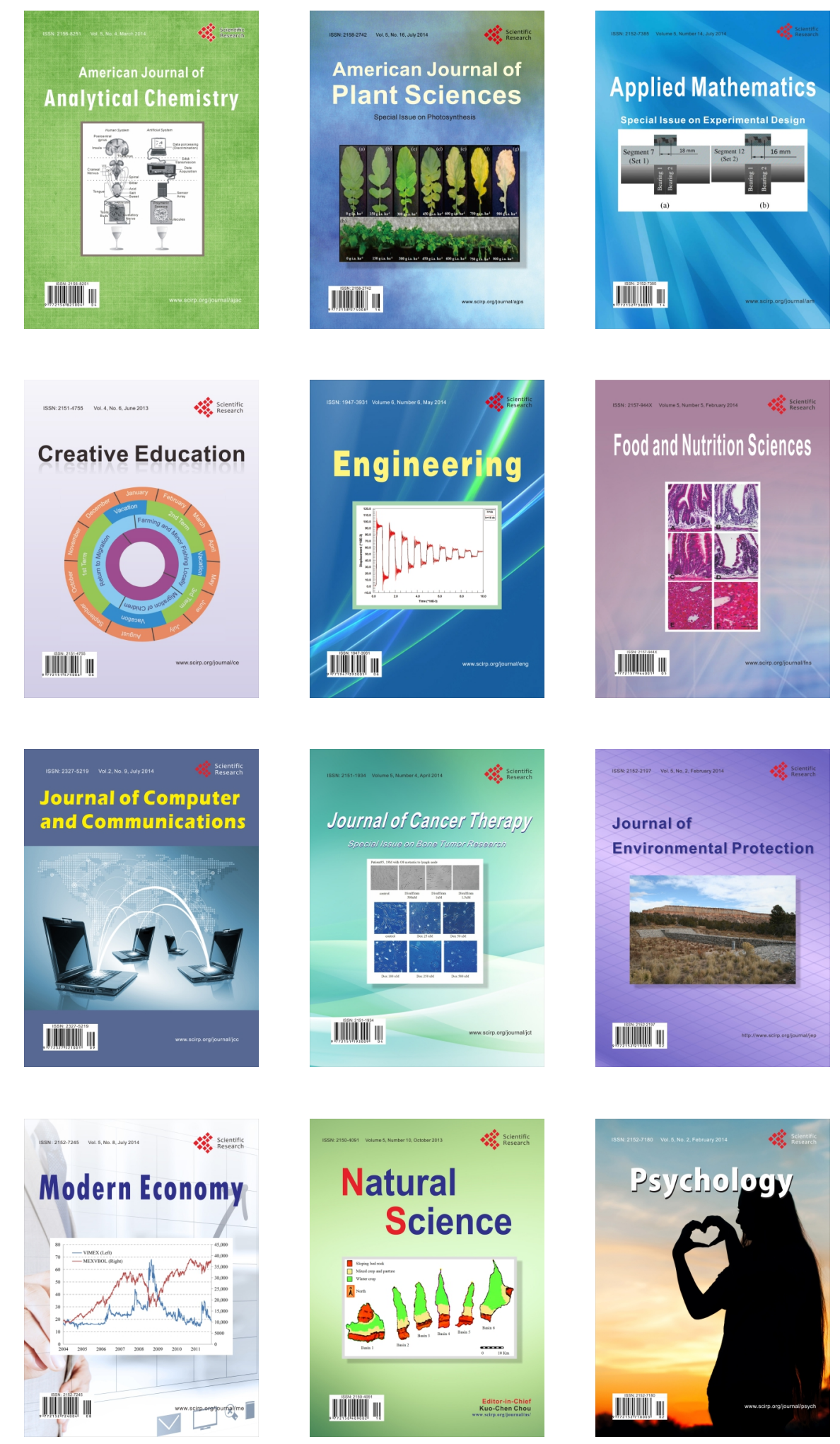